\title{
Management of Water Resources in Iraq: Perspectives and Prognoses
}

\author{
Nadhir A. Al-Ansari \\ Department of Civil, Environmental and Natural Resources and Engineering, \\ Luleå University of Technology, Luleå, Sweden \\ Email: alansari@ltu.se
}

Received April 19, 2013; revised May 19, 2013; accepted May 26, 2013

Copyright (C) 2013 Nadhir A. Al-Ansari. This is an open access article distributed under the Creative Commons Attribution License, which permits unrestricted use, distribution, and reproduction in any medium, provided the original work is properly cited.

\begin{abstract}
Iraq is one of the Middle East and North African countries (MENA region). The country is currently facing a serious water shortage problem. This problem is expected to be more severe in the future where the supply is predicted to be 43 and 17.61 Billion Cubic Meters (BCM) in 2015 and 2025 respectively while current demand is estimated to be between 66.8 and 77 BCM. It has been estimated that the Tigris and Euphrates river discharges will continue to decrease with time, and they will be completely dry by 2040 . Serious, prudent and quick measures need to be taken to overcome this problem. The government should take measures to have a strategic water management vision, including regional cooperation and coordination, research and development, improving agriculture and sanitation sector as well as public awareness program. These measures are required in order to address the following topics: Strategic Water Management Vision, Regional cooperation and coordination, Irrigation and Agriculture, Water Supply and Sanitation, and Research and Development.
\end{abstract}

Keywords: Water Management; Iraq; Water Resources of Iraq

\section{Introduction}

Middle East and North African countries (MENA region) are considered to be arid or semi-arid as the average annual rainfall does not exceed $166 \mathrm{~mm}[1,2]$. For this reason, the scarcity of water resources in the MENA region, and particularly in the Middle East, represents an extremely important factor in the stability of the region and an integral element in its economic development and prosperity [3-5]. Future predictions suggest more severe shortages to be expected both in surface and groundwater resources [6-9]. Due to the presence of Tigris and Euphrates rivers, Iraq was considered relatively rich in its water resources compared to its neighboring countries until the 1970s. During the 1970s Syria and Turkey started to construct dams on the Euphrates and Tigris Rivers which caused a major decrease in the flow of the Euphrates River [1] as well as deterioration of the quality of its water [10]. This fact highlighted a further concern over future water quotas and its alarming implications upon the national security and strategies.

Iraq is located in the eastern part of the MENA region. It is surrounded by Iran in the east, Turkey to the north, Syria and Jordan to the west, Saudi Arabia and Kuwait to the south and the Gulf to the southeast (Figure 1).The total area of Iraq is $438,320 \mathrm{~km}^{2}$ of which $924 \mathrm{~km}^{2}$ of inland water.

The population is about 20.4 million (1995) with a growth rate of $3.6 \%$ (1980-1990). About $25 \%$ of the inhabitants live in rural areas. The population density ranges from 5 to 170 inhabitants $/ \mathrm{km}^{2}$ in western desertic and the central part from the country respectively. This rate had dropped since 1989 due to severe economic hardship [1]. To pographically; Iraq is shaped like a basin containing the great Mesopotamian plain of the Tigris and Euphrates rivers. The climate is mainly of a continental, subtropical semi-arid type with the north and northeastern mountainous regions having a Mediterranean climate (Figure 2). The temperature during summer is usually over $430^{\circ} \mathrm{C}$ during July and August and drops down to $20^{\circ} \mathrm{C}$ and $160^{\circ} \mathrm{C}$ during the day and night respectively in winter time (Figure 3 ).

Meteorological records were used to calculate the evaporation and evapotranspiration values using the Penman method. The results show that the overall average evaporation and evapotranspiration are of the order of 1900 $\mathrm{mm}$ per year (Figure 4). 


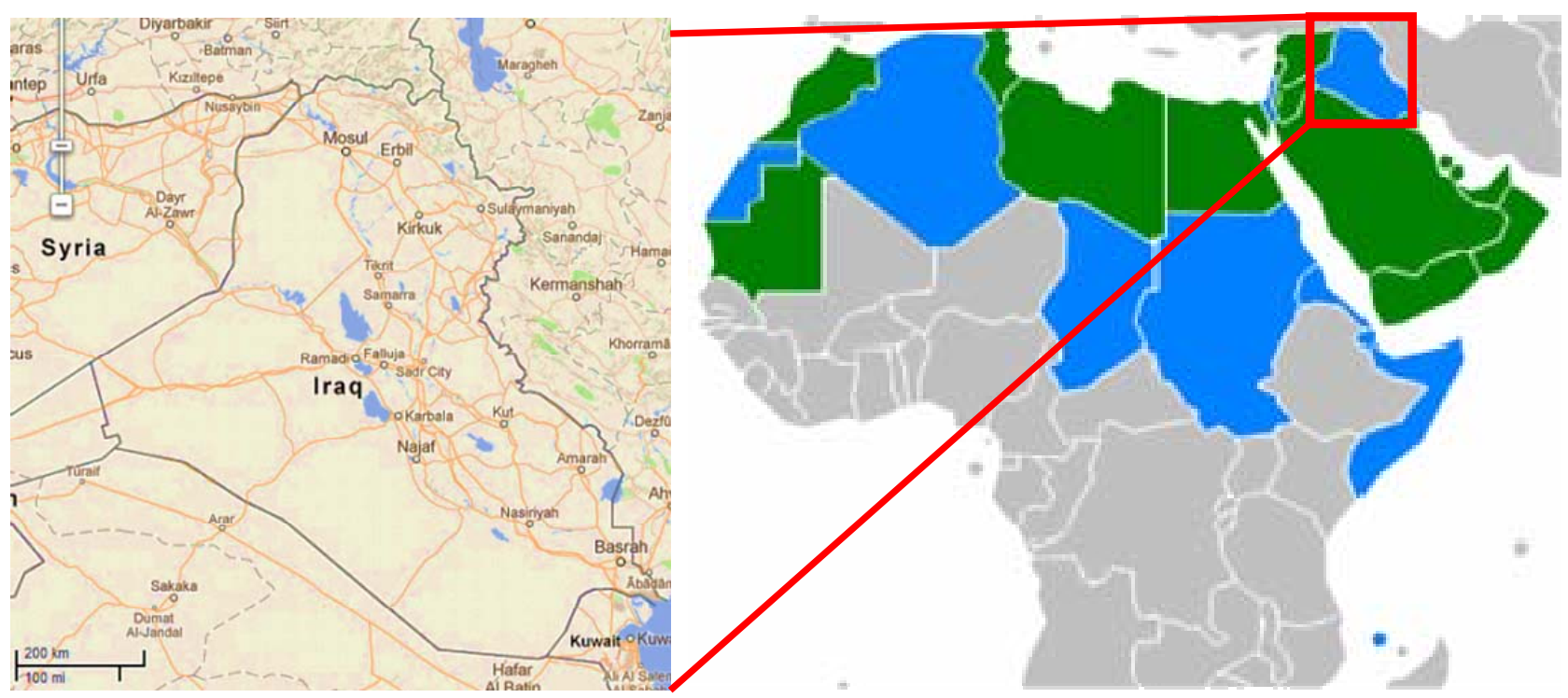

Figure 1. Location map of Iraq.

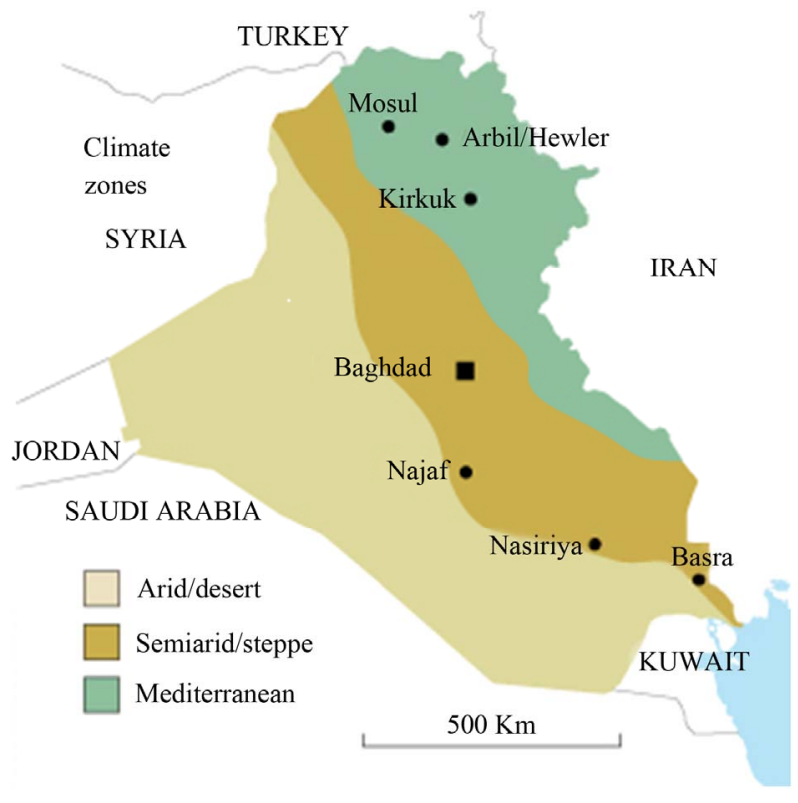

Figure 2. Climate zones of Iraq.

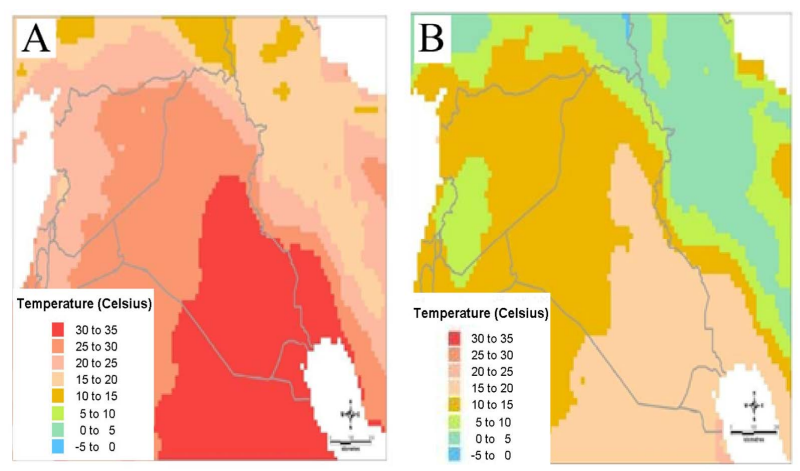

Figure 3. Maximum (A) and minimum (B) daily temperature.

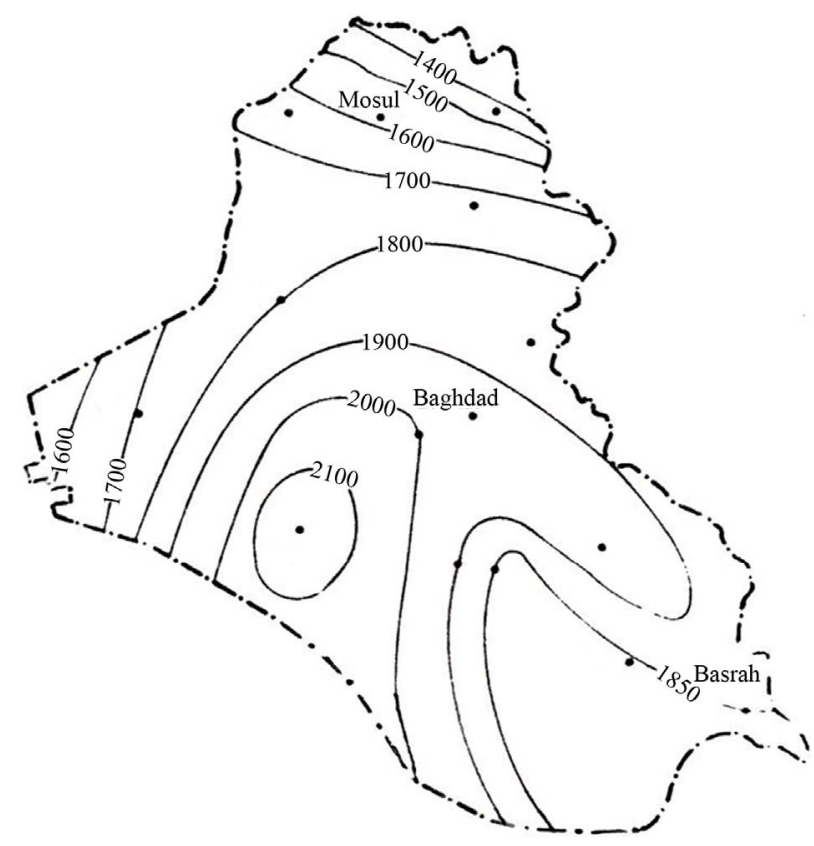

Figure 4. Average annual evaporation (mm).

Furthermore, the values show an increasing trend similar to that of the temperature increasing from the northeast towards the southwest (Figure 4) [11].

The average annual rainfall is $154 \mathrm{~mm}$ (Figure 5), but it ranges from less than $100 \mathrm{~mm}$ over $60 \%$ of the country in the south up to $1200 \mathrm{~mm}$ in the northeast. The rainy season is restricted between October to April [1,12,13].

The Rivers Tigris and Euphrates form the main water resources of Iraq. They join together in the south forming what is referred to as the Shat Alarab, which drains towards the Gulf (Figure 1). Most of the water from these rivers comes from Turkey (71\%) followed by Iran (6.9\%) 


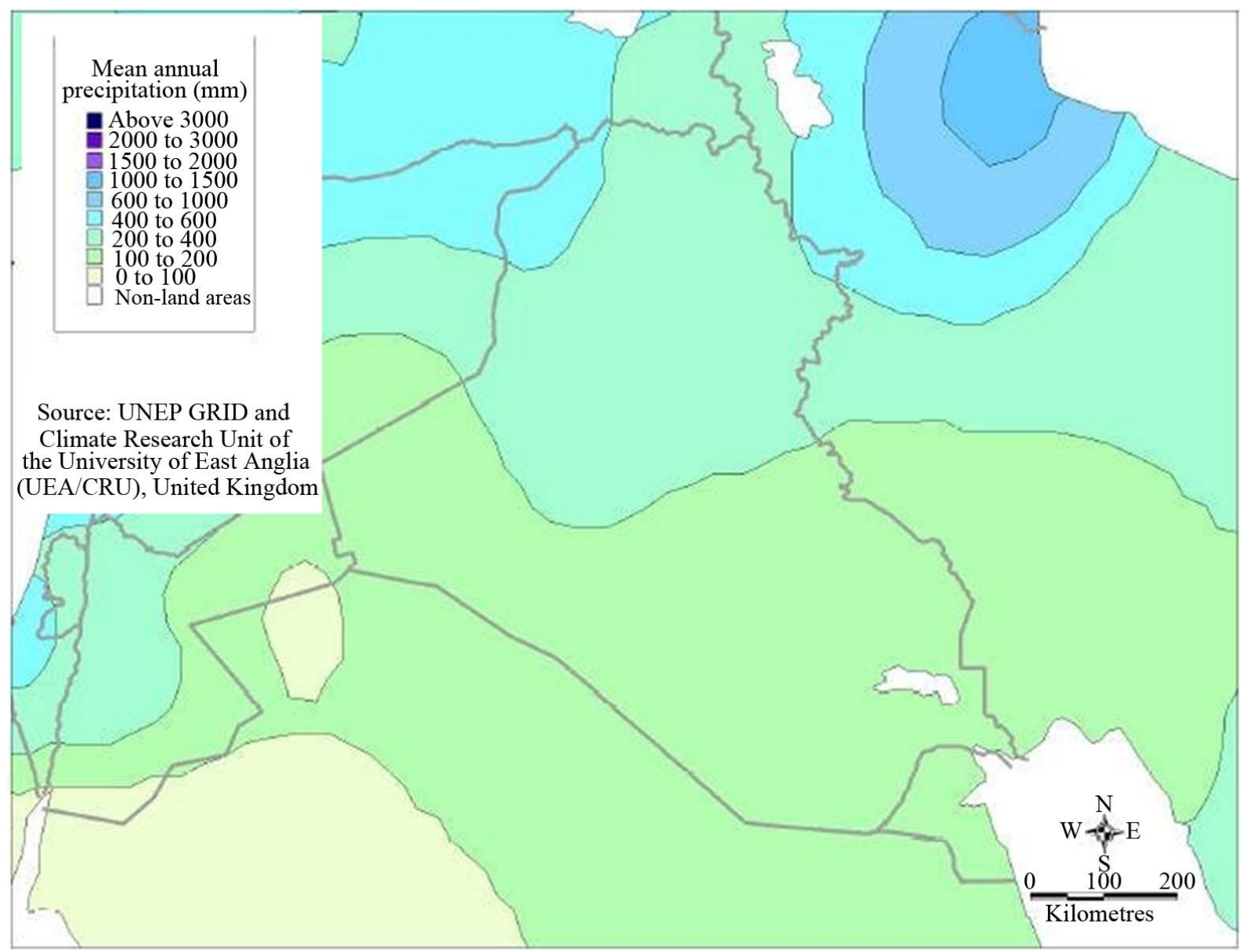

Figure 5. Mean annual rainfall.

and Syria (4\%). The remainder, only $8 \%$, is from internal sources (Figure 6). The average annual flow of the Euphrates and Tigris is estimated to be about $30 \mathrm{~km}^{3}$ (which might fluctuate from 10 to $40 \mathrm{~km}^{3}$ ) for the former and $21.2 \mathrm{~km}^{3}$ for the latter when it enters Iraq. Its tributaries contribute $24.78 \mathrm{~km}^{3}$ of water and there are about $7 \mathrm{~km}^{3}$ of water brought by small wadies from Iran, which drains directly towards the marsh area to the [1]. The World Bank [12] stated that $100 \%$ of the Euphrates water comes from outside the borders of Iraq while $67 \%$ of the Tigris water also comes from outside sources. They also stated that groundwater resources are about 1.2 BCM and form about $2 \%$ of the total water resources of Iraq.

The total water withdrawal in Iraq was about $42.8 \mathrm{~km}^{3}$ in 1990, which is used for agricultural $(90 \%)$, domestic $(4 \%)$ and industrial $(6 \%)$ purposes $[4,5,12,14]$. According to the most recent estimates, $85 \%$ of the water withdrawal is used for agricultural purposes [1]. It should be mentioned however, that safe water supplies (drinkable water) reach $100 \%$ of the urban areas and only $54 \%$ of rural areas. The situation had deteriorated after the Gulf war for both water and sanitation sectors. IMMPW [15] stated that $1 / 3$ of the population of Iraq does not have

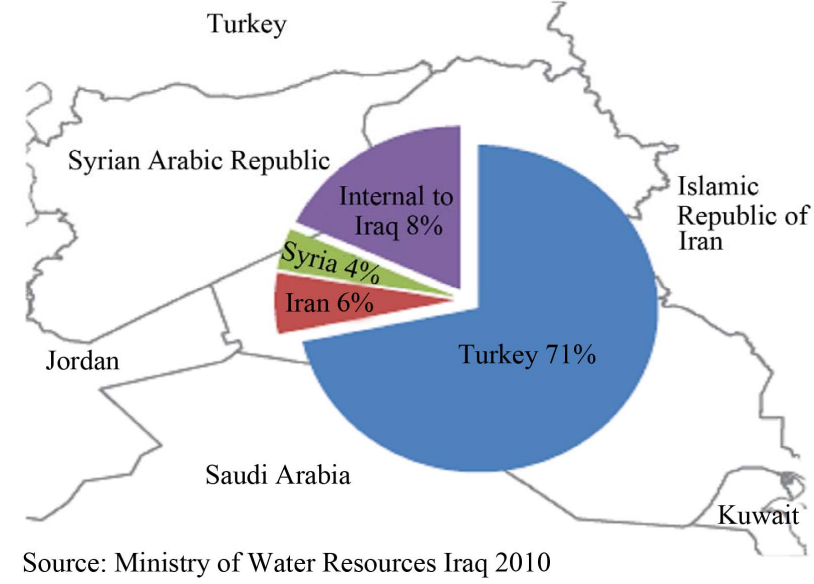

Figure 6. Sources of water for the Tigris and Euphrates Rivers (MWR, 2010).

access to potable water, and the quantity of water production is decreasing to $5,469,534 \mathrm{~m}^{3} /$ day which represents $53 \%$ of the water demand. The Iraqi government hopes to ensure water supplies reach $91 \%$ of the population by 2015 [16].

Since Sumerian times (7500 years ago) the land be- 
tween the Tigris and Euphrates has been irrigated by the water from these rivers. The suitable land for agriculture is 11.5 million ha, which represent $25 \%$ of the total area of Iraq [12]. The irrigation potential is $63 \%, 35 \%$ and $2 \%$ for the Tigris, Euphrates and Shat Alarab rivers respectively.

The area used for agriculture is 8 million hectares, which forms $70 \%$ of the total cultivated area. About $40 \%$ - $50 \%$ of this area is irrigable, and lies in the riverine plains while the remainder is rain fed and is located in the northeastern plains and mountain valleys. The irrigated area is mainly supplied by water from the main rivers, and only $7 \%$ is of the area is supplied by ground water [12]. Due to fallow practices and the unstable political situation only 3 to 5 million hectares are now actually cultivated annually. In 1993, it is believed that only 3.73 million hectares were cultivated of which 3.46 and 0.27 million hectares consisted of annual and permanent crops respectively [1]. Considering the soil resources, about 6 million hectares are classified as excellent, good or moderately suitable for flood irrigation. With the development of water storage facilities, the regulated flow increased and changed the irrigation potential significantly. It is well known that irrigation development depends to a large extent upon the volume of water released by the upstream countries. Existing data estimates that the contribution of the agricultural sector was only $5 \%$ of Gross Domestic Product (GDP) which is usually dominated by oil (more than 60\%). About $20 \%$ of the labour force is engaged in agriculture [1].

The Iraqi water strategy is highly influenced by the Euphrates water where $100 \%$ of its flow comes from outside the country. While only $50 \%$ of the Tigris flow comes from Turkey. According to the negotiations between riparian countries, Iraq is supposed to receive 58\% of the Euphrates flow, which crosses the Turkish-Syrian border, while Syria receives $42 \%$. Turkey promised in the past to secure minimum flows of $15.8 \mathrm{~km}^{3} /$ year at its border which gives Iraq $9 \mathrm{~km}^{3} /$ year. Up to now there has been no formal agreement between the three countries concerning the Euphrates and Tigris water. Present estimates indicate that Iraq is receiving only about $0.03 \mathrm{~km}^{3}$ / year of the Euphrates water [1].

In this research, the difficulties facing Iraq will be reviewed and discussed, and recommendations will be given to solve the problems of water resources in Iraq.

\section{Water Resources of Iraq}

\subsection{River Tigris}

The River Tigris rises in the southeastern part of Turkey on the southern slopes of the Touros mountain range and drains an area of $472,606 \mathrm{~km}^{2}$ which is shared by Turkey, Syria and Iraq. Its total length is about $1718 \mathrm{~km}$ (Table
1). About $58 \%$ of the basin lies in Iraq. Three major tributaries (Butman $\mathrm{Su}$, Karzan and Razuk) join the Tigris before it reaches the Turkish/Iraqi border. The mean annual flow of the river does not exceed $64 \mathrm{~m}^{3} / \mathrm{s}$ and it increases at Razuk to $413 \mathrm{~m}^{3} / \mathrm{s}$. It enters Iraq at Fiesh Khabur where the Khabur tributary joins the main river at a small distance to the south. The mean annual flow of the Khabur is $68 \mathrm{~m}^{3} / \mathrm{s}$. The River Tigris flows towards the south and reaches the first major city (Mosul). Its mean discharge at Mosul reaches $630 \mathrm{~m}^{3} / \mathrm{s}$.

The Greater Zab River joins the Tigris about $60 \mathrm{~km}$ south of Mosul. The confluence of the two rivers is situated midway between Mosul and Sharkat cities. This tributary drains an area of $25,810 \mathrm{~km}^{2}$ of which about $62 \%$ lies in Iraq. This tributary is one of the largest with a mean annual flow of $418 \mathrm{~m}^{3} / \mathrm{s}$.

Further south, the Lesser Zab tributary joins the Tigris at Fatha. This tributary drains an area of $21,476 \mathrm{~km}^{2}$ (25\% in Iran) with a mean annual flow of $227 \mathrm{~m}^{3} / \mathrm{S}$ whiles the mean annual flow of the Tigris reaches 1340 $\mathrm{m}^{3} / \mathrm{S}$ down-stream of this confluence. South of Fatha, the Adhaim tributary joins the Tigris. This tributary drains an area of $13,000 \mathrm{~km}^{2}$ and lies totally in Iraq [17]. The mean annual flow of this river reaches $25.5 \mathrm{~km}^{3}$. This tributary runs dry between June and November each year. Furher to the south, the last major tributary, the Diyala River joins the Tigris south of Baghdad. The Diyala basin is $31,846 \mathrm{~km}^{2}$ of which about $20 \%$ lie in Iran. The mean daily flow of this tributary is $182 \mathrm{~m}^{3} / \mathrm{s}$.

No major tributary joins the River Tigris south of Baghdad $[18,19]$. Few canals draw water from the Tigris in this region for irrigation purposes. For this reason, the mean annual daily flow of the river falls below its value at Baghdad $\left(1140 \mathrm{~m}^{3} / \mathrm{S}\right)$ in Kut and Amara cities at the south (Figure 7) [20].

The Tigris River mean discharge at Mosul city prior to 1984 was $701 \mathrm{~m}^{3} / \mathrm{S}$ and dropped to $596 \mathrm{~m}^{3} / \mathrm{S}$ afterward (Figure 4). This implies a 15\% decrease of the river discharge.

\subsection{River Euphrates}

The River Euphrates is $2781 \mathrm{~km}$ long and rises from the southeastern parts of Turkey. It drains an area of 444,000 $\mathrm{km}^{2}$ shared by four countries (Iraq $41 \%$, Turkey $28 \%$,

Table 1. Drainage area of the Tigris River basin.

\begin{tabular}{cc}
\hline Country & Catchment area $\left(\mathrm{km}^{2}\right)$ \\
\hline Turkey & 57,614 \\
Syria & 834 \\
Iraq & 253,000 \\
Total & 471,606 \\
\hline
\end{tabular}




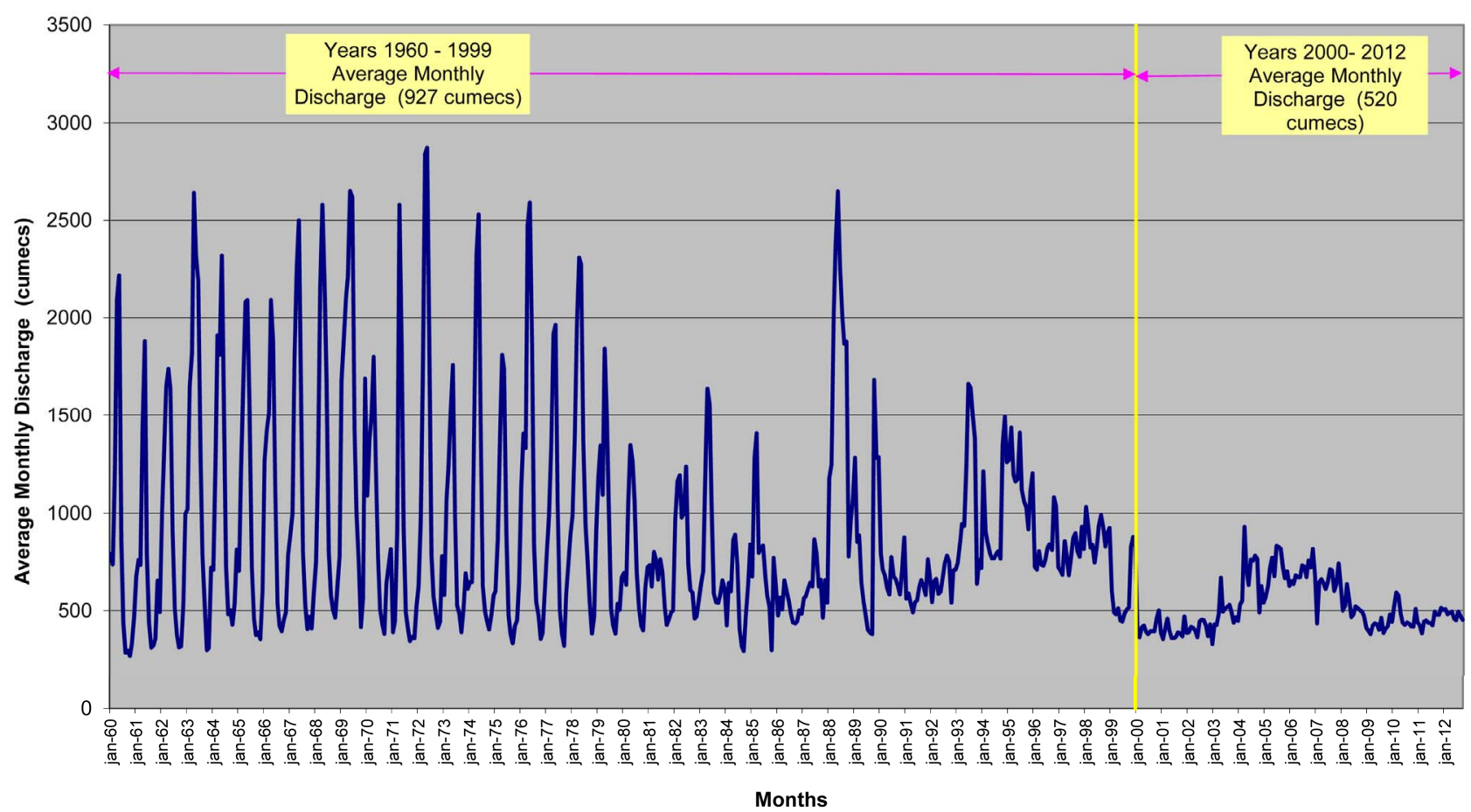

Figure 7. Average monthly recorded discharges of Tigris River at Sarai Baghdad station for the period 1960-2012 (Data source until 2007 from [20]).

Syria 17\% and Saudi Arabia 14\%) (Table 2). The Rivers Karah Su and Murad Su join together in the southeastern parts of Turkey at Kuban forming the River Euphrates. The River enters Syria at Jarablis where it runs $675 \mathrm{~km}$ and then enters Iraq. Thirty kilometers south of Jarablis, the Sajor tributary joins the Euphrates. Further downstream, two tributaries, the Balikh and Khabur, join the main river after which it crosses the Iraqi border at Hasaibah. The mean daily discharge of the Euphrates River inside Iraq (at Hit) is $909 \mathrm{~m}^{3} / \mathrm{s}$ [1,13,21]. Inside Iraq, no tributary contributes water to the river. The river supplies a number of small canals in the central and southern parts of Iraq for irrigation purposes (Figure 1). Some of its water is diverted to the Habaniya reservoir during floods, which is situated about $40 \mathrm{~km}$ south of Ramadi. About $135 \mathrm{~km}$ south of Faluja, the Hindiya barrage diverts a maximum discharge of $471.5 \mathrm{~m}^{3} / \mathrm{s}$ to small parallel tributaries [22].

The Euphrates channel south of Kifil is divided into two main channels (Kufa and Shamiya), and they joins again at Mushkhab (Figure 1).

Further downstream, the channel splits again about 25 $\mathrm{km}$ south of Shanafiya and rejoins near Simawa. Then the river enters Hamar marsh, where it forms two main channels within Hamar marsh. One of the channels (northern) joins the Tigris River at Qurna orming (known as the Shat Alarab River) while the other channel joins the Shat Alarab River at Karmat Ali.

The Euphrates River mean discharge at Hit and Ha-
Table 2. Drainage area of the Euphrates River basin.

\begin{tabular}{cc}
\hline Country & Catchment area $\left(\mathrm{km}^{2}\right)$ \\
\hline Turkey & 125,000 \\
Syria & 76,000 \\
Iraq & 177,000 \\
Saudi Arabia & 66,000 \\
Total & 444,000 \\
\hline
\end{tabular}

ditha cities prior to 1972 was $967 \mathrm{~m}^{3} / \mathrm{S}$ and dropped to $553 \mathrm{~m}^{3} / \mathrm{S}$ after 1985 (Figure 8). The percentage decrease in river discharge is $43 \%$.

\subsection{River Shat Alarab}

This river forms at Qurna where the Tigris and Euphrates Rivers join together, and it flows into the gulf (Figures 1 and 9). Its total length is $192 \mathrm{~km}$ and it drains an area of $80,800 \mathrm{~km}^{2}$ its annual discharge at FAO is $35.2 \mathrm{~km}^{3}$. Two main tributaries (Suwaib and Karun) join the main course of the river. Most of the flow of these tributaries is halted by Iranian water projects.

\subsection{Dams in Iraq}

The idea of building dams in Iraq started in the first half of the twentieth century. Primarily it was to protect Baghdad, the capital, and other major cities from flood- 


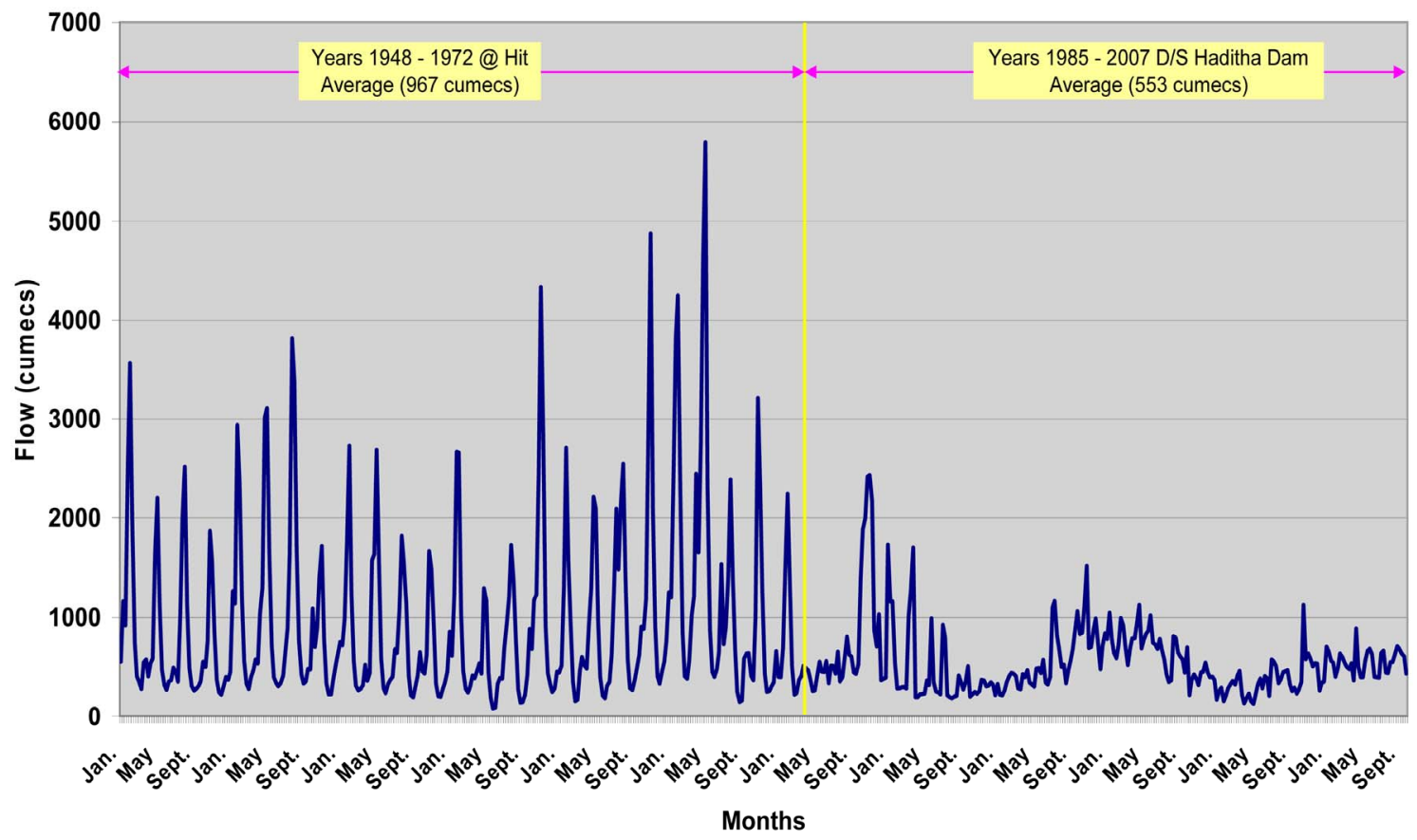

Figure 8. Water discharge of River Euphrates at Hit and Hadiththa Cities for the period 1948-2007.

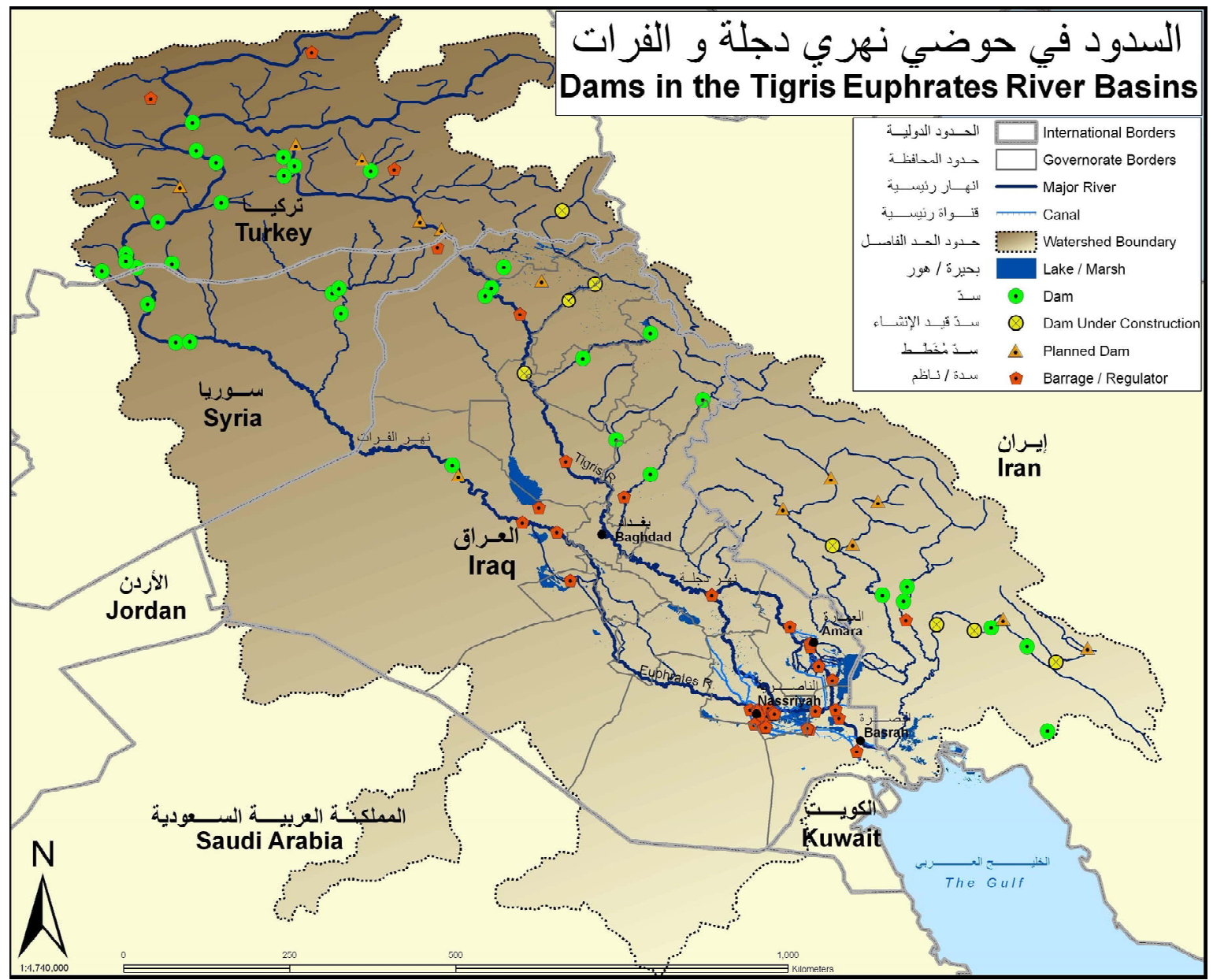

Figure 9. Location of dams in Tigris and Euphrates Rivers basin (source: [28]). 
ing. The first big dam (Dokan) was constructed in 1959 on the Lesser Zab River. Later, dams were constructed for irrigation and power generation purposes (Table 3) $[23,24]$. The Iraqi Government realized the process of building dams should be speeded up due the huge increase of water demand and the threat of reduced water in the rivers by Turkey and Syria. The process stopped in the 1990s due to the second Gulf war and UN sanctions. None of these dams were filled to their maximum storage capacities during the twenty first century. This is due to the depletion of flow in the Euphrates and Tigris Rivers by the Turkish and Syrian dams. It is noteworthy that the Haditha dam is almost of no use now due to the severe depletion of the Euphrates flow. In addition there were few concerning and worrying circumstances with some of the existing dams where, Mosul dam was built on highly soluble, fractured and jointed gypsum beds $[25$, 26]) which left this dam at a high risk of collapse [27]. Furthermore, rock sliding at Darbandikhan reservoir close to the dam wall required the water level in this reservoir to be kept high to ensure the stability of the sliding rocks (Figure 9) [28].

\section{Factors Affecting Water Resources}

\subsection{Regional}

\subsubsection{Global Climate Change}

The MENA region is among the most vulnerable in the world to the potential impacts of climate change [29]. The most significant changes in a region which already suffers from aridity, recurrent drought and water scarcity are the increased average temperatures, less and more erratic precipitation, and sea level rise (SLR).

Records of temperature highs in 2010 show that five countries from the MENA region including Kuwait $\left(52.6^{\circ} \mathrm{C}\right)$, Iraq $\left(52.0^{\circ} \mathrm{C}\right)$, Saudi Arabia $\left(52.0^{\circ} \mathrm{C}\right)$, Qatar $\left(50.4^{\circ} \mathrm{C}\right)$, and $\operatorname{Sudan}\left(49.7^{\circ} \mathrm{C}\right)$ were among the top 19 countries affected [30].

The MENA region contains hyper-arid, arid and semiarid zones (Figure 10) [31]. Several research projects have concluded that arid and semi-arid regions are highly vulnerable to climate change [32]. It is expected that the region will suffer from higher temperatures and intense heat waves affecting inhabitants and crop yields, and will also affecting marine ecosystems and fisheries. Less but more intense rainfall, coupled with higher temperatures will likely cause more droughts and greater flooding, sea level rise, more intense cyclones and new areas exposed to dengue, malaria, and other vector and waterborne diseases.

It is very likely that 20th century global warming has expanded the size of seas and oceans resulting in a loss of land ice [33]. Through the period of 1961-2003, it was observed that the global sea level rise was about $1.8 \mathrm{~mm}$ per year while during the period 1993-2003 it reached up to $3.1 \mathrm{~mm}$ per year [34].

AFED [29] and Dasgupta et al. [35], reported that the Gulf will be highly vulnerable at its northern tip north in Kuwait and in the south of Iraq (Shatt el Arab) to SLR (Figures 11 and 12). Despite the limited coastline Iraq

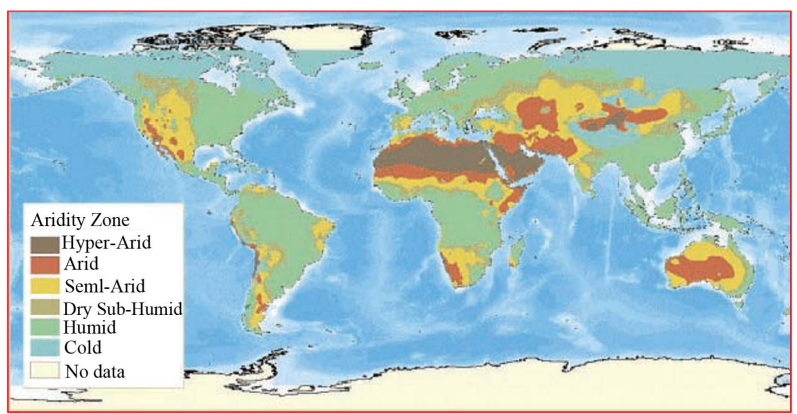

Figure 10. Aridity zones of the world (Source: [31]).

Table 3. Dams of the Rivers Tigris and Euphrates basins in Iraq.

\begin{tabular}{ccccc}
\hline River Basin & River & Dam & Reservoir Capacity $\left(\mathrm{km}^{3}\right)$ & Year of Construction \\
\hline Tigris & Lesser Zab & Dokan & 6.8 & 1959 \\
Tigris & Diyala & Darbandikhan & 2.8 & 1961 \\
Tigris & Diyala & Hemrin & 2.4 & 1981 \\
Tigris & Tigris & Al-Mosul & 11.11 & 1986 \\
Tigris & Robardo & Dohuk & 0.475 & 1988 \\
Tigris & Udhaim & Al-Udhaim & 1.5 & 1999 \\
Euphrates & Euphrates & Haditha & 8.28 & 1986 \\
Tigris & Greater Zab & Bakhma & 17 & Partially Constructed \\
Tigris & Tigris & Badoush & 10 & Partially Constructed \\
Euphrates & Euphrates & Al-Baghdadi & 0.499 & Partially Constructed \\
\hline
\end{tabular}




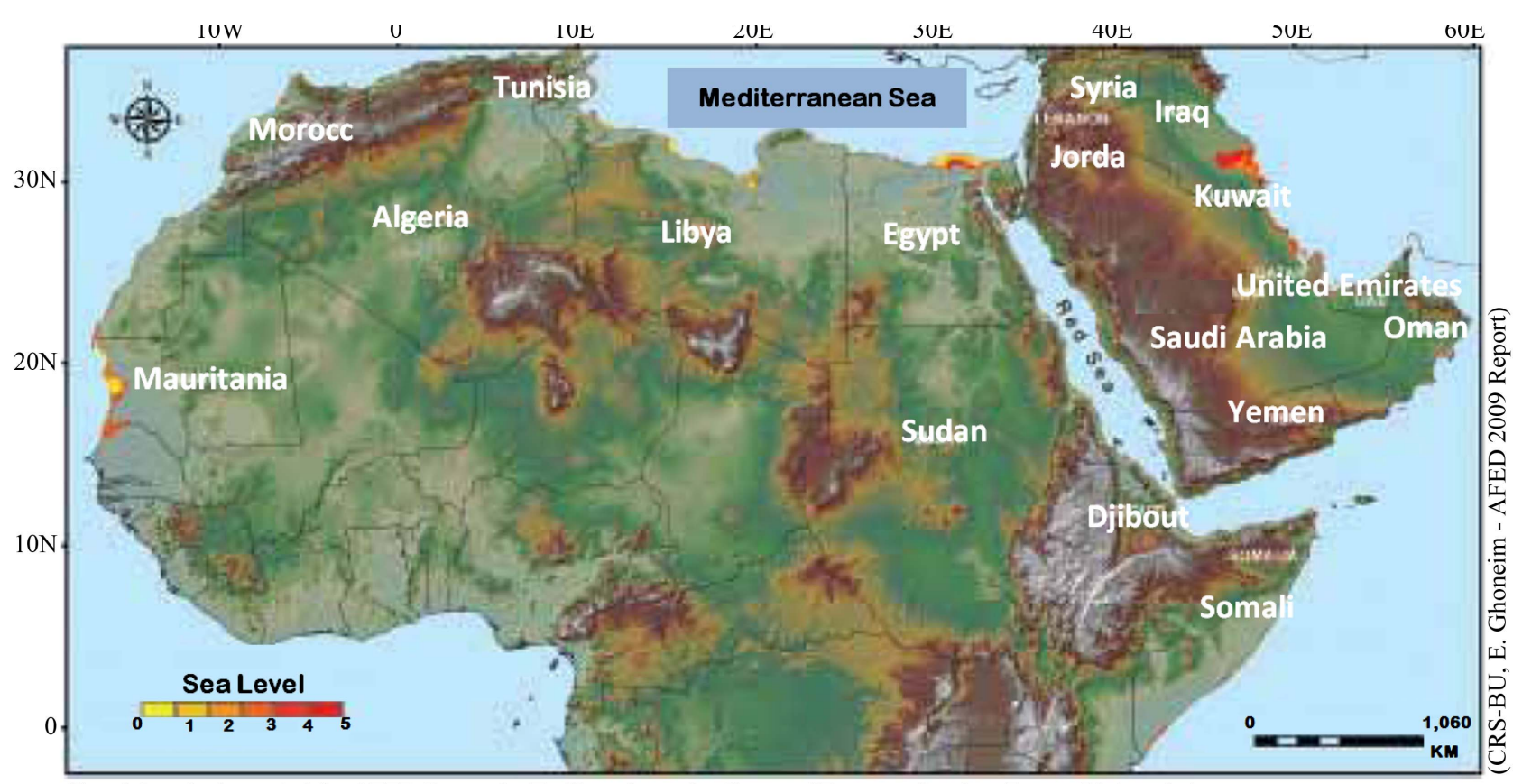

(Special analysis carried for AFED Report by E. Ghoneim at the Center of Remotet Sensing, Boston University)

Figure 11. Sea level rise for Arab countries (Source: [37]).

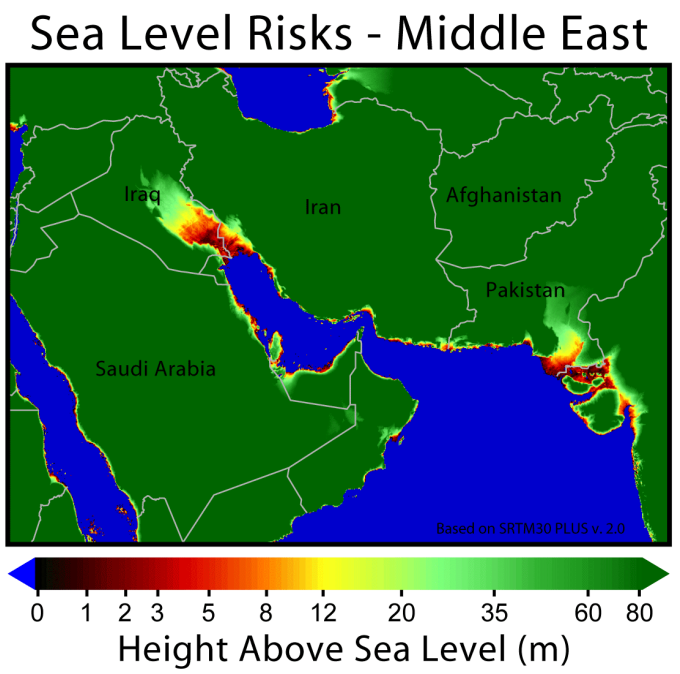

Figure 12. Effect of sea level rise on Iraq and Kuwait, Source [37].

has in the Gulf region, the vulnerable low land areas exten The combination of the climate change impact and rapid trends of population growth, FAO projections indicate that Algeria, Egypt, Morocco, Syria and Tuni-sia are expected to experience severe water shortages by 2050 , and only Iraq is expected to be in a relatively better situation [36-38].

Arnell [39] indicated that by the end of the 21st century, the flow of rivers in the Middle East will be decreased due to climatic changes; however, the magnitude of change is highly uncertain.

The drought will affect the agricultural life and water supply in the MENA region [40]. This is due to the fact that most of the agricultural areas of the MENA region are rain-fed [41]. For example about one-third of Iraq's cereal production (wheat and barley) is produced under rain-fed conditions in the north [42].

Dust storms may lead to aerosol pollution which changes cloud properties and then reduces precipitation in the polluted region. In the desert land, the limited precipitation will help to produce more dry soil which leads to produce more dust in the air [43]. AL-Bayati [44], indicated that eleven factors have an effect on the frequency of dust storms in Iraq, the most effective being relative humidity while evaporation and cloud cover were the lowest. For the past few years, Iraq has experienced a number of dust storms. Figure 13 shows a thick dust created from the border of Iraq with a southwest moving front passing Saudi Arabia and the Red Sea to reach Egypt [36].

At the end of the century the mean temperatures in the MENA region are projected to increase by $3{ }^{\circ} \mathrm{C}$ to $5^{\circ} \mathrm{C}$ while the precipitation will decrease by about $20 \%$ [45]. Water run-off will be reduced by $20 \%$ to $30 \%$ in most of MENA by 2050 [32] and water supply might be reduced by $10 \%$ or greater by 2050 [46]. The weather events will include more droughts and floods. Mediterranean water level is predicted to rise between $30 \mathrm{~cm}$ and 1 metre by the end of the century causing flooding to coastal areas along the Nile Delta [34].

CGCM3.1 (T47) model with the A2 scenario was chosen in order to simulate the average monthly temperature and rainfall on Iraq for the historical period 1900-2009, 


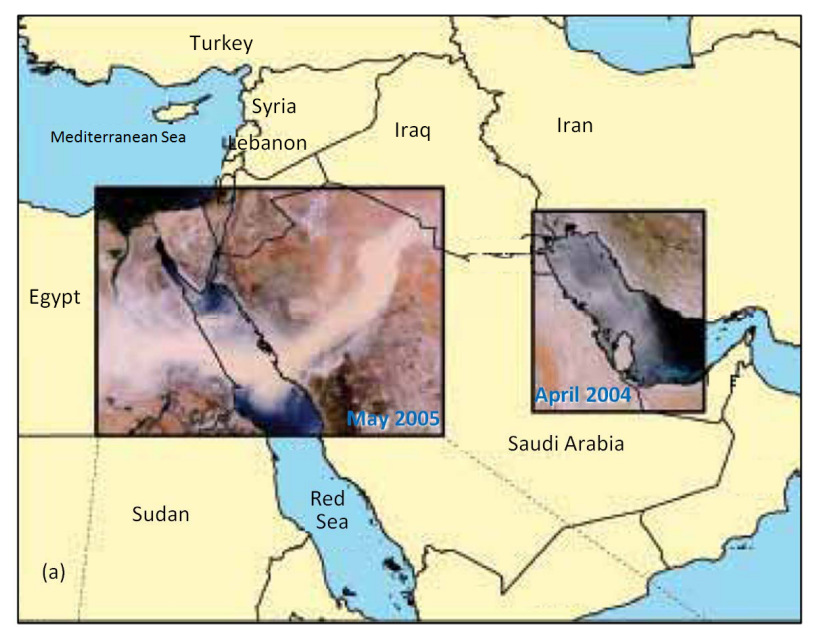

Figure 13. A thick dust moving from southwest of Iraq passing Saudi Arabia and then the Red Sea to reach Egypt (after [36]).

and for mean future projected temperature and rainfall until 2099 [47]. The data were obtained from [48].

The data set is produced by the Climatic Research Unit (CRU) of University of East Anglia (UEA), and reformatted by the International Water Management Institute (IWMI). Both 1900-2009 and 2020-2099 periods were divided into four periods (1900-1930, 1930-1960, 19601990, and 1990-2009) and (2020-2039, 2040-2059, 20602079, 2080-2099). The results are shown in Figures 14 and 15.

A comparison between the values of annual temperatures (Figure 14) shows that the increase of annual temperature was limited during the historical period 19002009 , but the increase is more noticeable during the period 2020-2099. The rainfall trend (Figure 15) shows an increase till 1960 followed by a decrease up to 2009. Furthermore it is expected that rainfall will increase again until 2039 followed by a decrease to 2099 .

The summation of average monthly rainfall (average annual) for the four historical periods (First 1900-1930, second 1930-1960, Third 1960-1990 and Fourth 19902009) was as follows $182.5,194.7,168.9$, and $162.6 \mathrm{~mm}$, respectively. The total rainfall value had increased by $12.2 \mathrm{~mm}$ from 1930 to 1960 with a percentage increase of up to $6.68 \%$. Moving from 1960 to 1990 the total rainfall decreased by $25.8 \mathrm{~mm}$, with a percentage decrease of up to $13.25 \%$. While moving from 1990 to 2009 the total rainfall fell again by $6.3 \mathrm{~mm}$, with a percentage decrease of up to $3.73 \%$.

The maximum total summation of the rainfall (average annual) was fell from $194.7 \mathrm{~mm}$ during the period of 1930-1960 to reach its lowest value of $162.6 \mathrm{~mm}$ during 1990-2009. The future predicted part in Figure 15 shows that an increase and decrease of the total summation of the rainfall (average annual) through the four periods of

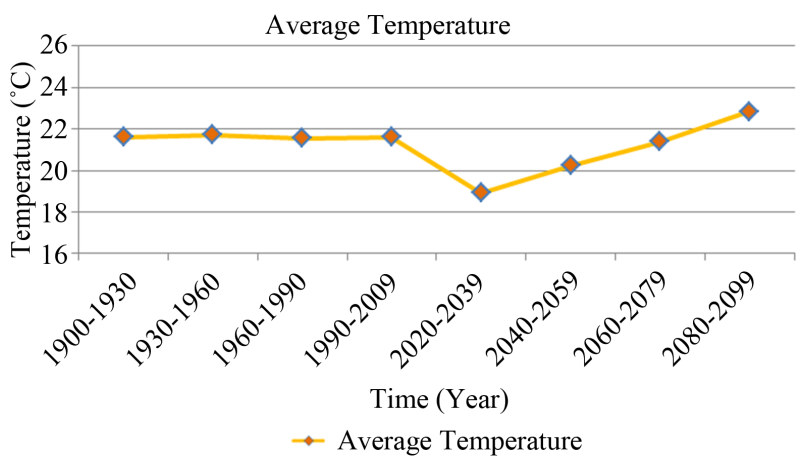

Figure 14. Average annual temperature over the historical and future study periods.

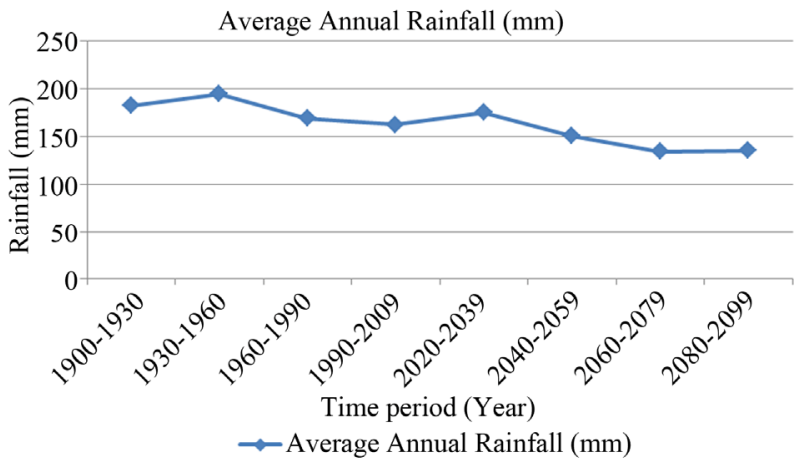

Figure 15. Average annual rainfall (mm) over the study historical and future periods.

2020-2039 (175.41 mm), 2040-2059(150.96 mm), 20602079 (134.59 mm), and 2080-2099 (135.31 mm) in Iraq.

Considering the average monthly rainfall (average annual) of the first future period (2020-2039) represents the rainfall benchmark for all future periods, the differences in total rainfall over the four periods reached up to 24.45 , 16.37 , and then it increased by $0.72 \mathrm{~mm}$ respectively. Where the percentage reduction reached up to $13.93 \%$, $10.83 \%$, and then increased by $0.53 \%$, in general, the summation of average monthly rainfall (average annual) tends towards reduction in its values.

\subsubsection{GAP Project}

In 1977, the Turkish government set up a project referred to as Southeastern Anatolia Project (GAP) [49]. The main components of the project include 22 dams and 19 hydraulic power plants which are supposed to irrigate $17,000 \mathrm{~km}^{2}$ of land (Table 4) [50]. The estimated time for the completion of the project was $2010[49,50]$ but due to financial, technical and political problems it is still not completed. The overall volume of water to be captured is about $100 \mathrm{~km}^{3}$ which is three times more than the overall capacity of Iraqi and Syrian reservoirs. The project is supposed to develop the southeastern provinces which cover $9.7 \%$ of the total area of Turkey which forms $20 \%$ of the agricultural land of the country. De- 
Table 4. Dams of the GAP project in Turkey.

\begin{tabular}{ccc}
\hline River Basin & Name of the Dam & Year of Completion \\
\hline Ataturk & 1992 \\
Birecik & 2000 \\
Camgazi & 1998 \\
Hancagrz & 1988 \\
Karakaya & 1987 \\
Karkamis & 1999 \\
Euphrates & Buykcay & Suggested \\
& Catallepe & Suggested \\
& Gomikan & Suggested \\
& Kahta & Suggested \\
& Kayacik & Suggested \\
Kemlin & Suggested \\
& Koeali & Suggested \\
Sirmtas & Suggested \\
& Batman & 1998 \\
Dicle & 1997 \\
Kralkizi & Cigris \\
& Cizre & Suggested \\
& Garzan & Suggested \\
& Kayser & Suggested \\
& Ilsu & Under construction \\
& Silvan & Suggested \\
\hline
\end{tabular}

spite the continuous instance of the Turkish Government that GAP is purely a development project, it seems that there are number of internal and external goals involved [51-55]. In addition to the GAP dams, Syria built three major dams with a total storage capacity of $16.1 \mathrm{~km}^{3}$ (Table 5). The construction of these dams is for irrigation and electricity generation [56].

GAP is designed to irrigate 1.82 million hectares [49] that means that the required water for irrigation is about $29 \mathrm{~km}^{3}$ while the reservoirs of the project store $100 \mathrm{~km}^{3}$.

Turkish, Syrian and Iraqi water requirements from River Euphrates are 15.7, 11 and $13 \mathrm{~km}^{3}$ respectively to irrigate all the cultivated lands. It should be noted, however, that other authors had cited different figures for the water requirement for Turkey, Syria $\left(7.95 \mathrm{~km}^{3}\right)$ and Iraq $\left(19 \mathrm{~km}^{3}\right)$ [57]. When GAP project is completed, $80 \%$ of the Euphrates water will be controlled by Turkey [58-60]. Syria used to receive $21 \mathrm{~km}^{3} /$ year of the Euphrates water prior 1990 which dropped to $12 \mathrm{~km}^{3}$ from 2000 onward ( $40 \%$ reduction). As far as Iraq is concerned, the volume of the water received dropped from $29 \mathrm{~km}^{3}$ before 1990 [61] to $.4 \mathrm{~km}^{3}$ (90\% reduction) now. Due to this agricultural used land in both countries has reduced from 650,000 hectares to 240,000 hectares. In addition, the quality of water deteriorated due to back water irrigation directed toward the main channel in its upstream reaches [1]. When Ilisu dam is constructed on the Tigris River, Iraq will recieve only $9.7 \mathrm{~km}^{3}$ [62]. This implies that
Table 5. Dams of the River Euphrates in Syria.

\begin{tabular}{ccc}
\hline Dam & Storage Capacity $\left(\mathrm{km}^{3}\right)$ & Year of Operation \\
\hline Forat & 14.163 & 1978 \\
Baath & 0.09 & 1989 \\
Teshreen & 1.883 & 2000 \\
Total & 16.135 & \\
\hline
\end{tabular}

$47 \%$ of the river flow will be depleted. This in turn means that 696,000 hectares of agricultural land will be abandoned due to water scarcity [1].

Water demand does not exceed $15.6 \mathrm{~km}^{3} /$ year in Turkey while the overall water supplies reach $195 \mathrm{~km}^{3} /$ year [57]. If we consider the existing population growth rate in Turkey, then its population will be 91 million in 2025 then the demand will be $26.28 \mathrm{~km}^{3}$. This fact has been reflected on by the Turkish Government where it offered to export 500 million $\mathrm{m}^{3}$ of water/year to Israel [1].

The fact that Turkey can exert virtual control over the water of the Tigris and Euphrates Rivers is of vital concern to Iraq which depends so much on these two rivers for much of its water supply. The collapse of water levels in the rivers has been swift where it dropped in the Euphrates from 950 before 2005 to less than $230 \mathrm{~m}^{3} / \mathrm{s}$ now. We can summarize the consequences as follows:

The upstream development on the Euphrates and Tigris Rivers will contribute to water depletion in Iraq which will increase with time. This will reduce the quantity of water entering Iraq from the Euphrates River from $9-21$ BCM to 9 BCM or less which represents a drop from $75 \%$ to $28 \%$ [12].Syria is planning to double its irrigated area $(740,000 \mathrm{ha})$ which will increase its water withdrawal from $5 \mathrm{BCM}$ to $9 \mathrm{BCM}$ [12].This will cause:

- Diminishing water for agriculture;

- Land degradation due to expected high salinity;

- More drying of the Basra marshes causing more ecological damage;

- Further deterioration of the already bad water quality of the Euphrates (TDS is $1800 \mathrm{mg} / \mathrm{L}$ now);

- Less hydropower generation;

- Rising the risk of regional conflict [63];

- Demographical implications where farmers and fishermen will leave their homes;

- Lower groundwater levels.

\subsection{National Issues}

\subsubsection{Supply and Demand}

Despite the differences in numbers given by various sources, there is an overall agreement that there is a gap between supply and demand $[1,12,16,64]$. The overall estimate of water required is 75 to $81 \mathrm{BCM}$ [12]. Irrigation consumptive use reached $39 \mathrm{BCM}$ in 1991 and in 
$2003 / 4$ it was $22 \mathrm{BCM}$ equivalent to $44 \mathrm{BCM}$ of water derived, assuming 50\% irrigation efficiency. Real efficiency might be $25 \%$ - 35\% [12]. The agricutural land cropped is about 1.9 million ha in recent years out of 3.5 million ha. If all this area is cropped then the water requirement is $50 \mathrm{BCM}$ assuming good irrigation efficiency.

The demand from the sanitation sector is about 5BCM and due to the fact the infrastructure system is out of service, losses have increased. It should be mentioned however, that the demand of the industrial sector decreased. Hydropower use including the evaporation from reservoirs reaches $10 \mathrm{BCM}$ /annum. Restoring the marshes requires $16 \mathrm{BCM}$ and demand for in-stream flow reaches 3 $\mathrm{BCM} /$ annum.

UN [16] and Stockholm International Water Institute (SIWI) [65] estimates indicate that available water in Iraq reaches $75 \mathrm{BCM}\left(2400 \mathrm{~m}^{3}\right.$ per person per year which is more than neighboring countries with the exception of Turkey (Figure 16).

The overall water demand excluding restoring the marshes is about $73 \mathrm{BCM}$ and the available water is about 59 - 75 BCM. If the situation remain as it is the Iraqi water supplies will drop to $43 \mathrm{BCM}$ by 2015 and to 17.61 in 2025 (UN, 2010) and the demand is $66.85 \mathrm{BCM}$ [66] or 77BCM [67].

It should be noted however that the quality of water deteriorates from north to south along both the Tigris and Euphrates Rivers where it approaches a salinity of about $2000 \mathrm{mg} / \mathrm{l}$ in Basra [15]. According to the World Bank (2006), the Iraqi water deficit in 2030 will reach 25.55 BCM (37\%) where the expected supply is 44 BCM only. Recent reports state that the Tigris and Euphrates rivers will be completely dry by 2040 [16].

\subsubsection{Distribution Network}

Water usage in Iraq is about 350 liters/capita/day [15]. Safe water supplies used to reach $100 \%$ and $54 \%$ of the urban and rural areas in 1991. The situation deteriorated in both quality and quantity afterwards and $33 \%$ of the population do not have access to safe water and sanitation $[1,15]$.

Current estimates indicate that water supply to urban areas is $73 \%$ and in rural areas $40 \%-45 \%$ of requirements. Water services are limited to a few hours per day and it is of poor quality. Multiple Indicator Cluster Sur-

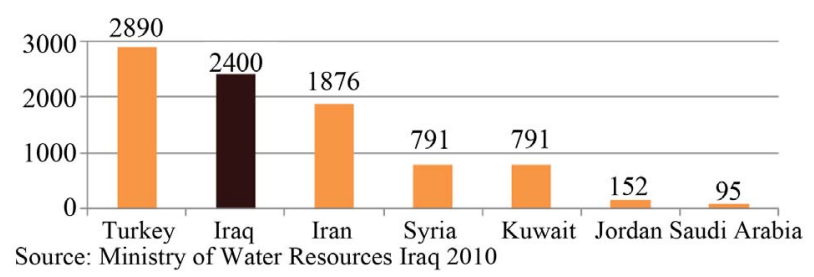

Figure 16. Water allocation in some MENA countries. vey (MICS) [68] indicated that $79 \%$ of the population has access to drinking water $(92 \%$ in urban and $57 \%$ in rural areas). It was also stated that those having access to drinking water it takes about 21 minutes in urban areas (42 minutes in rural areas) to get to the source to bring water for $17 \%$ of all households. The same survey showed that $21 \%$ have no access to drinking water, and $16 \%$ have daily problems while $7 \%$ have weekly problems, $15 \%$ have less than weekly problems and only $41 \%$ have a reliable source. According to [15] domestic water shortage is $1.7 \mathrm{MCM} /$ day but if the percentage per capita is decreased, there will be excess water (Table 6).

The demand is about 11 million cubic meters per day while the supply is half that amount [15]. The Iraqi government hopes to ensure water supplies to $91 \%$ of the population by 2015 [16]. The scenarios given by [15] are based on lower ongoing consumption level (Table 6). The efficiency of the distribution network is very poor (32\%) [12] and it is deteriorating with time. For this reason water allocation per capita has been decreasing with time since 1980 [69].

\subsubsection{Sanitation}

About $92 \%$ of the population of Iraq is living in households using improved sanitation and $82 \%$ of this category use flush toilets connected to sewage systems or septic tanks or latrines (Figure 17) [70]. Improved sanitation is $98 \%$ and $82 \%$ in urban and rural areas respectively. Only $48 \%$ have their toilets connected to pipe sewer systems in metropolitan areas, 57\% have septic tanks in urban areas and $36 \%$ flush their toilets to latrines which is very common in rural areas. In reality, most of the of the sewage treatment plants and septic systems do not function properly and as a result there is an overflow of the effluent into the environment [68].

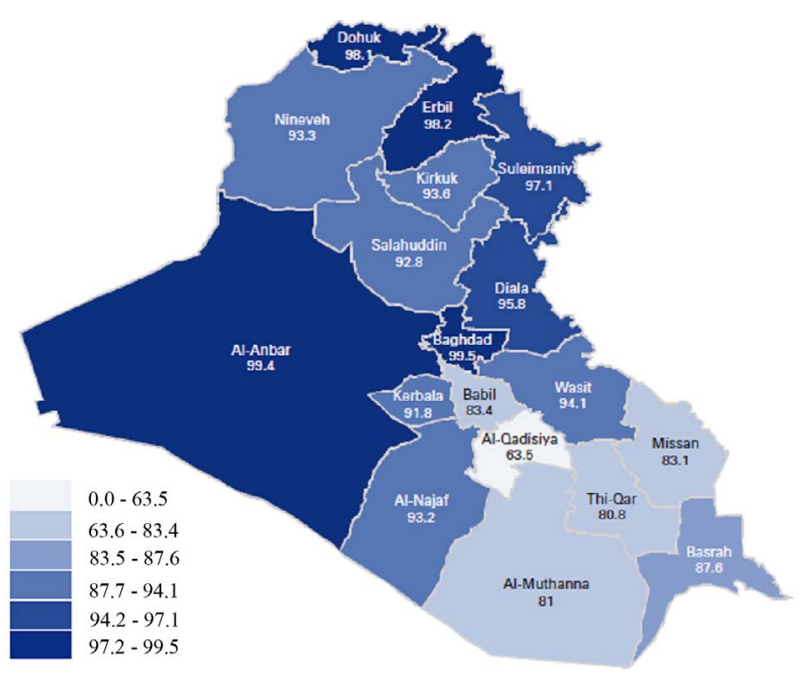

Figure 17. Percentage of household using sanitary means of excreta disposal, by governorate, Iraq, 2005 (source [70]). 
Table 6. Scenarios of domestic water availability and demand (source of data [15]).

\begin{tabular}{ccccc}
\hline $\begin{array}{c}\text { Water Usage } \\
\text { (liters/capita/day) }\end{array}$ & Population (millions) & $\begin{array}{c}\text { Water Demand/Day } \\
\text { (million cubic meters) }\end{array}$ & $\begin{array}{c}\text { Water Supply/Day } \\
\text { (million cubic meters) }\end{array}$ & $\begin{array}{c}\text { Balance } \\
\text { (million cubic meters/Day) }\end{array}$ \\
\hline 350 & 24 & 8.5 & 6.8 & -1.7 \\
250 & 24 & 6 & 6.8 & 0.8 \\
200 & 24 & 3.6 & 6.8 & 3.2 \\
\hline
\end{tabular}

Only 14 cities out of 252 urban centers have a wastewater treatment plant [12]. Wastewater treatment capacity reaches 350,000 cubic meters per day and this serves $8 \%$ of the population. Most if not all the sewage and sewarage systems require replacement, rehabilitation and upgrading. It should be mentioned however that $70 \%$ of the sewage water is discharged untreated directly to rivers [12]. Damaged waste water systems and drinking water networks are causing mix of water and as a result many people are infected by sewage related diseases $[12$, $68,70,71]$.

\subsubsection{Water Quality}

Water quality of the Tigris and Euphrates is poor due to the return flows from irrigation projects. Inside Iraq, most of the irrigation returns flow is directed to the third drain river which drains to the Gulf. Some of the Tigris flood flows are diverted to Tharthar Lake which is highly saline, and then it is redirected for use in the river system with the salt washed from the lake. The expansion of irrigation in Turkey and Syria will cause a further deterioration in the water quality. In addition, direct discharge of raw sewage into the rivers and industrial effluents are causing more damage [68]. It was also noticed that over 500,000 cubic metres of raw sewage are discharged into rivers each day, and the rapid increase in water salinity poses an urgent challenge.

TDS values of the Tigris water at the Turkish Iraqi border is $280-275 \mathrm{mg} / \mathrm{l}$ and it reaches more than 1800 $\mathrm{mg} / \mathrm{l}$ in Basra [15]. The TDS of Euphrates water at the Iraqi-Syrian border is $600 \mathrm{mg} / \mathrm{l}$ and increases to more than $1300 \mathrm{mg} / \mathrm{l}$ downstream at Samawa $[12,15]$. The situation might be worse on the tributaries where TDS values in the Diyala River reaches $3705 \mathrm{mg} / \mathrm{l}$ [72].

The quality of drinking water does not meet WHO standards or Iraqi national water quality standards [66]. Leakage, in both drinking water distribution and sewerage systems causes high contamination. In view of this situation large number of the population are suffering from various diseases [16,70,73].

\subsubsection{Desertification}

Declining water flow of the Tigris and Euphrates Rivers, the repeated frequency of drought [74], water quality degradation and increasing soil salinity mean that large areas of Iraq are facing serious problems of desertifica- tion. It is believed that at least $45 \%$ of the area of Iraq has been substantially affected by desertification [75]. In addition, during the Gulf wars, huge number of palm trees were destroyed which originally were acting as natural barriers against the expansion of desertification. In view of the above, a large number of farmers and fishermen left their land and villages were deserted. The expansion of desert areas led to frequent sand or dust storms. Between 2007 and 2009, 40\% of cropland area experienced reduced crop coverage and 20,000 rural inhabitants left their homes (Figure 18) [66].

Iraq experienced salinity 3800 years ago [76]. In 1970 about $50 \%$ of the areas in central and south Iraq were degraded due to water logging and salinity. This forced the government to undertake a land rehabilitation program and a total of 700,000 ha were reclaimed. Later the situation deteriorated where recent estimates indicate that $4 \%$ of irrigated areas are severely saline, $50 \%$ are of medium salinity and $20 \%$ are slightly saline [76].

\subsubsection{Marshes}

The Iraqi marsh lands, which are known as the Garden of Eden, cover an area about 15,000 - 20,000 sq. $\mathrm{km}$ in the lower part of the Mesopotamian basin where the Tigris and Euphrates Rivers flow (Figure 19) [77]. The marshes lie on a gently sloping plan which causes the two rivers to meander and split into branches forming the marshes and lakes. The marshes had developed after a series of transgressions and regressions of the Gulf sea water.

The marshes lie on the thick fluvial sediments carried by the rivers in the area [78,79].

The area has played a prominent part in the history of mankind and was inhabited since the dawn of civilization by the Summarians who occupied the area before 6000 BP. The area was considered among the largest wetlands in the world and the greatest in western Asia where it supports a diverse range of flora and fauna and human populations of more than 500,000 persons and is a major stopping point for migratory birds $[16,79]$. It has been estimated that $60 \%$ of the fish consumed in Iraq comes from the marshes. In addition oil reserves have been discovered in and near the marshlands.

The Saddam regime began to drain the marsh lands so that troops could be moved into that area and use the water to block the advances of Iranian troops and perhaps 


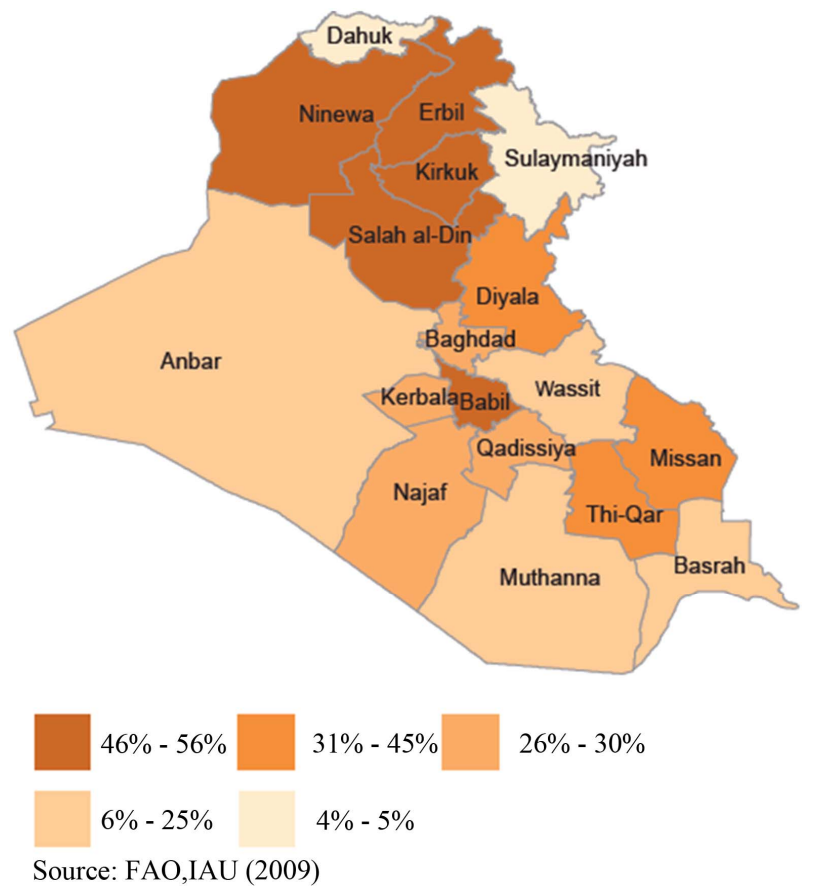

Figure 18. Affected cropland/percentage of cropland (source: [66]).

to get rid of the marsh dwellers due to the fact they participated in reprisals against him in $1991[73,79]$. To enable the army to move inside the marshes, the central government started to execute five major drainage projects to prevent water from the Tigris and Euphrates Rivers from reaching the marshes. Later, the army launched a major attack against marsh dwellers using artillery, mortar and ground attacks. The area was highly contaminated by army munitions and poison gas [79].

Accordingly, two third of the marshes were not receiving water inputs in 1993 and by 2000 less than 10\% remained (Figure 19). The consequences were that most of the marsh dwellers left their homes and some animals and plants are extinct now. The government at that time, to change the entire environment of the marshlands, implemented many agricultural projects in the dried areas of the marshlands. The total areas invested in these projects are $1920 \mathrm{~km}^{2}$ distributed over three governorates which are Thi-Qar, Maissan and Basrah [79].

After the fall of the Saddam regime in 2003, the Iraqi government, with the help of other countries and international organizations, started the process of restoration and rehabilitation of the Iraqi marshes. There are number of difficulties encountered in the process such as land use changes, climatic variations and changes in soil and water salinity as well as ecological fragmentation where many species were affected as well as the marsh dwellers themselves.

It is believed that $70 \%-75 \%$ of the original areas of the marshes can be restored [79]. The exact areas are
1800, 1800 and $2425 \mathrm{~km}^{2}$ for Al Hammar, Al Hawiza and the Central marshes. This implies that 12,886 MCM water should be available to achieve this goal keeping the water quality as it is [79]. If the water quality can be improved then $18863 \mathrm{MCM}$ of water is required. The World Bank [12] estimated that $10-16 \mathrm{BCM} /$ year is required to restore the marshes. This requires plenty of effort and international cooperation to overcome the existing obstacles.

\section{Conclusions and Recommendations}

Iraq is facing water shortage problems due to various factors involved. Some of these factors like global warming and the GAP project cannot be solved independently or in short term actions or planning. In addition, these themes need to be addressed with regional and international cooperation. However there are other issues which can be solved independently in a relatively short period of time. These are water losses in the distribution networks, drinking water quality, development of irrigation techniques etc. It has been noted by various researchers and organizations that the problem is becoming more alarming with time where the gap between supply and demand is increasing. The supply will be 43 and 17.61 BCM in 2015 and 2025 respectively while current demand is estimated between 66.8 to $77 \mathrm{BCM}$. In addition to all this, it has been reported that Tigris and Euphrates discharges will continue to decrease with time and they will be completely dry up by 2040 .

All these facts taken together suggest that the Iraqi government needs to take quick, prudent and firm action as a high priority. The action should address the following points:

- Strategic Water Management Vision should include: This plan should be an integrated long term "National Water Master Plan" needs to be designed and put in practice immediately. Such a plan should be the outcome of the work of the Ministry of Water Resources, Water Resources staff at Universities, private sector, NGO's and representatives of regional and International organizations concerned. It should include improving the efficiency of distribution networks specially diversion and supply down to the point of use which is most cost effective and Irrigation modernization using suitable techniques. Present techniques should be very restricted and new less water consuming techniques should be adopted e.g. drip irrigation. Rehabilitation of infrastructure which should cover dams, barrages, weirs as well as pumping stations is also required.

Defining institutional agenda including employment and training should be well planned. Supply and demand should be considered. In this context new nonconventional water resources (water harvesting, treated 


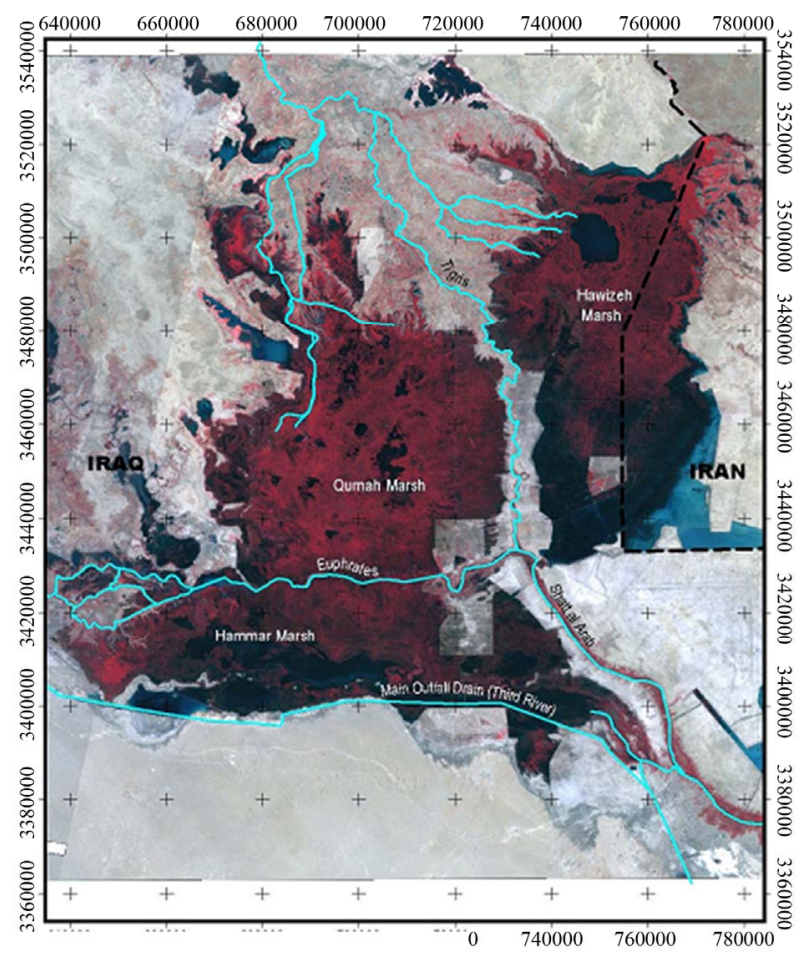

(a)

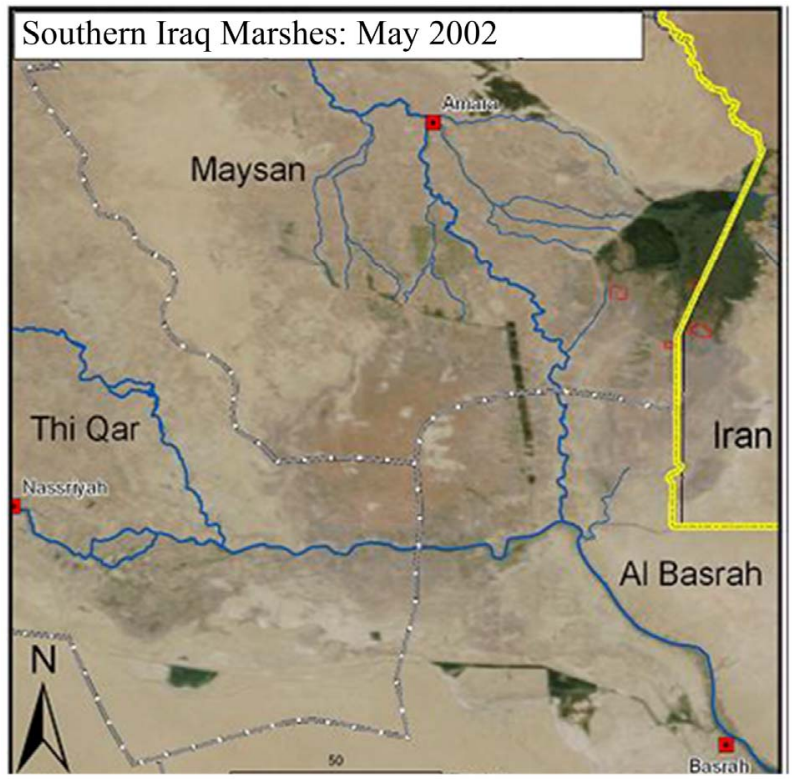

(c)

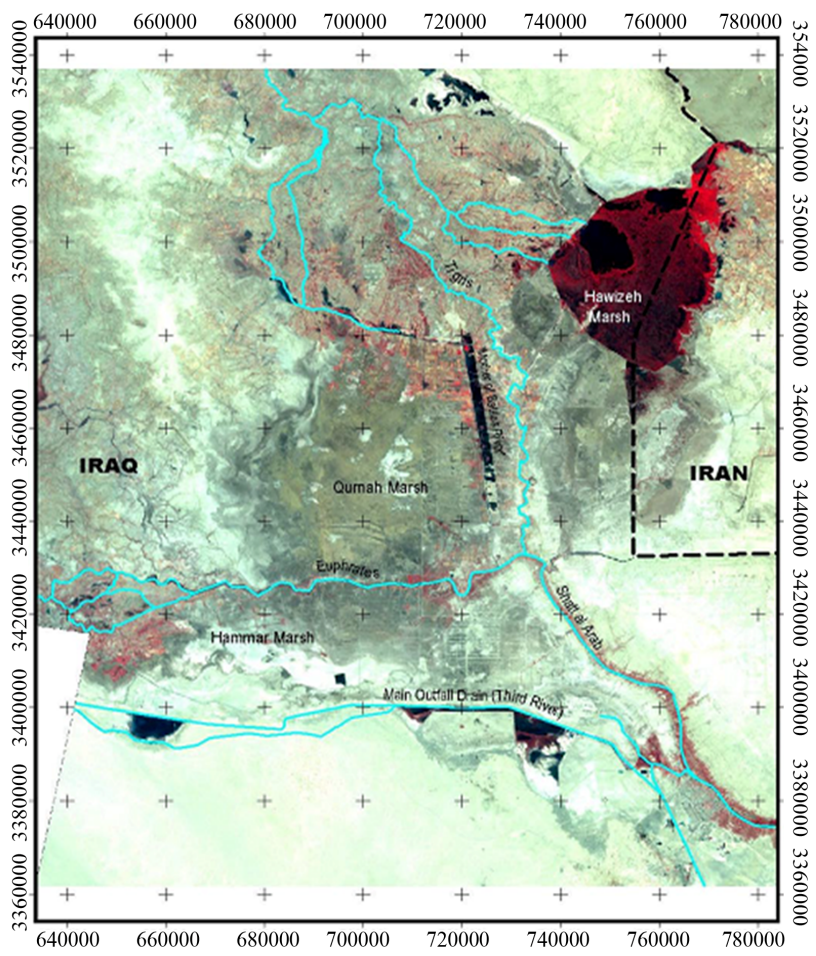

(b)

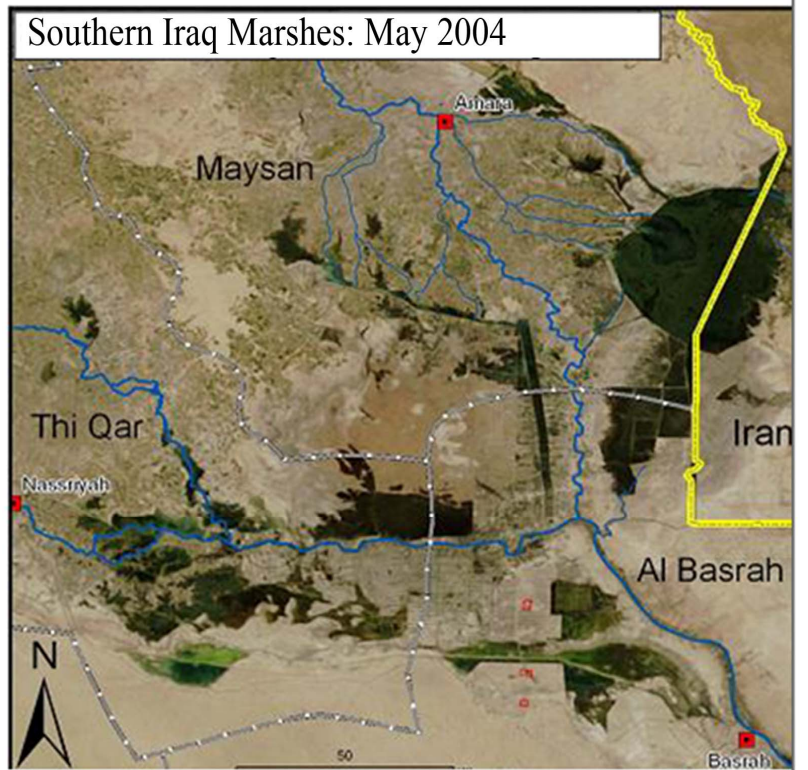

(d)

Figure 19. The Mesopotamian Marshes (a) 1985 (b) 2000 (c) 2002 (d) 2004 (source [77]).

waste water) should be considered and evaluated. Private sector is to be enhanced to be involved (especially for infrastructure investment. Inter-ministerial coordination is very important. This will save time, effort and money. More decentralization including budget in irrigation, water supply and sanitation sectors are to be practiced. Restoring the marshes should be considered.
Public awareness program is vital so that all the people appreciate the serious problem they are facing.

- Regional cooperation and coordination:

Defining institutional and technical needs for cooperation is to be set.

Cooperation on trans-boundary resources should be taken seriously. Iraq, Turkey, Iran and Syria are to coordinate their efforts to reach reasonable agree- 
ments with riparian countries on water quotas.

UN organizations (e.g. UNEP, UNDP, UNESCO etc.) and International institutions and organizations (FAO, WMO etc.) and universities should be approached to benefit from their experiences and expertise.

- Irrigation and Agriculture

Modernization of irrigation and drainage system is a must.

Institutions should reflect decentralization, autonomy and farmer empowerment and private investment in the agricultural sector should be enhanced. Public awareness program for farmers to use new suitable techniques in irrigation (drip irrigation and sprinkler irrigation) must be considered.

Maintenance of irrigation and drainage projects should be carefully planned and partially built dams should be completed and measure is to be taken to build the suggested dams and irrigation projects. This will increase the storage capacity of dams about $27 \mathrm{~km}^{3}$.

- Water Supply and Sanitation

Maintenance and restoring Distribution and collection networks should be maintained and restored and new projects should be put in practice. Services (e.g. using ICT) should be improved.

Non-conventional methods to augments water recourses are to be used. It is believed that water harvesting techniques can be very effective and are relative cheap cost wise.

- Research and Development

Two types of Data Banks using reliable data which can be accessed by the public and another for researchers should be established.

Research should be encouraged to import new technologies in water resources and agriculture which suites Iraq environment. Training programs for technicians, engineers and decision makers about up to date technologies should be well planned and executed and projects of pioneer nature which help in augmenting water resources, developing land productivity, minimizing water use and consumption.

Universities and institutes should set special courses in arid region hydrology.

\section{Acknowledgements}

The author would like to express his sincere thanks to Professor Ian Foster of Northampton University, UK for his suggestions and help during the preparation of this paper. Thanks to Mrs. Semia Ben Ali Saadaoui of the UNESCO-Iraq for her encouragement and support.

The research presented has been financially supported by Luleå University of Technology, Sweden and by "Swedish Hydropower Centre-SVC" established by the Swedish Energy Agency, Elforsk and Svenska Kraftnät together with Luleå University of Technology, The Royal
Institute of Technology, Chalmers University of Technology and Uppsala University. Their support is highly appreciated.

\section{REFERENCES}

[1] N. A. Al-Ansari and S. Knutsson, "Toward Prudent Management of Water Resources in Iraq," Journal of Advanced Science and Engineering Research, Vol. 1, 2011, pp. 53-67.

[2] R. Roger and P. Lydon, Eds., "Water in the Arab Word: Perspectives and Prognoses," Harvard University, Cambridge, 1993, pp. 101-120.

[3] T. Naff, "Conflict and Water Use in the Middle East," In: R. Roger and P. Lydon, Eds., Water in the Arab Word: Perspectives and Prognoses, Harvard University, Cambridge, 1993, pp. 253-284.

[4] N. A. Al-Ansari, "Water Resources in the Arab Countries: Problems and Possible Solutions," UNESCO International conference on Water: A Looming Crisis, Paris, 1998, pp. 367-376.

[5] N. A. AL-Ansari, “Applied Surface Hydrology," Al-Bayt University Publication, 2005.

[6] K. A. Voss, J. S. Famiglietti, M. H. Lo, C. Linage, M. Rodell and S. Swenson, "Groundwater Depletion in the Middle East from GRACE with Implications for TransBoundary Water Management in the Ti-Gris-EuphratesWestern Iran Region," Water Resources Research, Vol. 49, No. 2, 2013, pp. 904-914. doi:10.1002/wrcr.20078

[7] J. Chenoweth, P. Hadjinicolaou, A. Bruggeman, J. ELieveld, Z. Levin, M. A. Lange, E. Xoplaki and M. Hadjikakou, "Impact of Climate Change on the Water Resources of the Eastern Mediterranean and Middle East Region: Modeled 21st Century Changes and Implications," Water Resources Research, Vol. 47, No. 6, 2011, pp. 1-18. doi:10.1029/2010WR010269

[8] N. A. Al-Ansari, E. Salameh and I. Al-Omari, "Analysis of Rainfall in the Badia Region," Al Al-Bayt University Research Paper No. 1, Jordan, 1999, p. 66.

[9] F. Bazzaz, "Global Climatic Changes and Its Consequences for Water Availability in the Arab World," In: R. Roger and P. Lydon, Eds., Water in the Arab Word: Perspectives and Prognoses, Harvard University, Cambridge, 1993, pp. 243-252.

[10] A. H. Kamel, S. O. Sulaiman and S. Mustaffa, "Study of the Effects of Water Level Depression in Euphrates River on the Water Quality," Journal of Civil Engineering and Architecture, Vol. 7, No. 2, 2013, pp. 238-247.

[11] N. A. Al-Ansari, "Water Resources and Environment of Iraq," Internal Report, Lulea University, Lulea, 2010, p. 71.

[12] World Bank, "Iraq: Country Water Resources, Assistance Strategy: Addressing Major Threats to People's Livelihoods," Report No. 36297-IQ, 2006, p. 97.

[13] N. A. Al-Ansari, H. I. Assaid and V. N. Salim, "Water Resources in Iraq," Journal of the Geological Society, Vol. 15, 1981, pp. 35-42. 
[14] A. Sadik and S. Barghouti, "The Water Problems of the Arab World: Management of Scarce Resources," In: R. Roger and P. Lydon, Eds., Water in the Arab Word: Perspectives and Prognoses, Harvard University, Cambridge, 1993, pp. 1-38.

[15] IMMPW Iraqi Ministry of Municipalities and Public Work, "Water Demand and Supply in Iraq: Vision, Approach and Efforts," 2011. http://www.mmpw.gov.iq/

[16] United Nations, "Water Resources Management White Paper," United Nations Assistance Mission for Iraq, United Nations Country Team in Iraq, 2010.

[17] N. A. Al-Ansari, A. Sayfy, A. A. Ovanessian and G. T. Al-Sinawi, "Water Quality of the River Tigris North of Baghdad Using Multivariate Analysis," Journal of Water Resources, Vol. 5, No. 2, 1986, pp. 148-172.

[18] N. A. Al-Ansari, A. Sayfy, G. T. Al-Sinawi and A. A. Ovanessian, "Evaluation of the Water Quality for the Lower Reaches of River Tigris Using Multivariate Analysis," Journal of Water Resources, Vol. 5, No. 2, 1986b, pp. 173-187.

[19] N. A. Al-Ansari, H. H. Salman and G. T. Al-Sinawi, "Periodicity of Selected Water Quality Parameters for the Tigris Water at Baghdad," Journal of Water Resources, Vol. 6, No. 2, 1987, pp. 11-17.

[20] Q. Al-Shahrabaly, "River Discharges for Tigris and Euphrates Gauging Stations," Ministry of Water Resources, Baghdad, 2008 (in Arabic).

[21] N. A. Al-Ansari, N. Assad, D. E. Walling and S. A. Hussan, "The Suspended Sediment Discharges of River Euphrates at Haditha, Iraq," Geografisca Annaler, Vol. 79A, No. 3, 1988, pp. 203-213.

[22] M. Alsahaf, "Water Resources in Iraq," Ministry of Irrigation, Baghdad, 1976.

[23] General Commission for Dams and Reservoirs, Official Internet Site, Iraqi Government, 2009.

http://www.mowr.gov.iq/arabic/dams/small\%20dams $\% 20$ under\%20dicition.php

[24] Iraqi Parliament, "Dams of Iraq," Official Site of the Iraqi Parliament, 2009.

http://www.irqparliament.com/vb/showthread.php?t=303 87

[25] N. A. Al-Ansari, A. Gayara, A. Barazanji and M. AlJabbari, "Geological, Geophysical and Hydrological Investigation of Sadam Dam Area," Confidential Report, Ministry of Irrigation, Iraq, 1992.

[26] N. A. Al-Ansari, A. Gayara, A. Barazanji and M. AlJabbari, "Geological, Geophysical and Hydrological Investigation of Sadam Dams Reservoir," Confidential Report, Ministry of Irrigation, Iraq, 1993.

[27] J. Muir, "Iraqi Dam 'at Risk of Collapse'," BBC Official Site, 2007. http://news.bbc.co.uk/2/hi/middle_east/7069109.stm

[28] University of Victoria, "Dams in the Tigris Euphrates River Basins," Online Map, 2010. http://hdl.handle.net/1828/2400

[29] AFED (Arab Forum for Environment and Development), "Impact of Climate Change on Arab Countries," 2009. http://www.afedonline.org

[30] D. Verner and F. El-Mallah, "Adaptation to a Changing Climate in the Arab Countries," MNA Flagship Report, Sustainable Development Department, Middle East and North Africa Region, 2011.

[31] WRI, World Resources Institute, "Drylands, People, and Ecosystem Goods and 8 Services: A Web-based Geospatial Analysis," 2002. http://www.wri.org

[32] IPCC (Intergovernmental Panel on Climate Change), "Climate Change 2007: Climate Change Impacts, Adaptation and Vulnerability," Cambridge University Press, Geneva, 2007.

[33] IPCC, "Climate Change 2001: The Scientific Basis, Contribution of Working Group I to the IPCC," Third Assessment Report, Cambridge University Press, Cambridge, 2001.

[34] IPCC (Intergovernmental Panel on Climate Change), "Climate Change 2007: The Physical Science Basis," Cambridge University Press, Cambridge, 2007.

[35] S. Dasgupta, B. Laplante, C. Meisner and J. Yan, "The Impact of Sea Level Rise on Developing Countries: A Comparative Study," World Bank Policy Research Working Paper 4136, 2007.

[36] E. Ghoneim, "Remote Sensing Study of Some Impacts of Global Warming on the Arab Region," In: M. Tolba and N. Saab, Eds., Arab Environment Climate Change, Report, The Arab Forum for Environment and Development, Chapter 3, 2009, pp. 31-46.

[37] Global Warming Art License, "Middle East Sea Level Risks," 2007.

http://www.globalwarmingart.com/wiki/File:Middle_East Sea_Level_Risks_png

[38] FAO, "The State of Food and Agriculture, 2002," Food and Agriculture Organization of the United Nations, Rome, 2002.

[39] N. W. Arnell, "Climate Change and Global Water Resources: SRES Scenarios and Socio-Economic Scenarios," Global Environmental Change, Vol. 14, No. 1, 2004, pp. 31-52. doi:10.1016/j.gloenvcha.2003.10.006

[40] M. Medany, "Impact of Climate Change on Arab Countries," Chapter 9, 2008.

www.afedonline.org/afedreport/english/book9.pdf

[41] T. Oweis and A. Hachum, "Water Harvesting and Supplemental Irrigation for Improved Water Productivity of Dry Farming Systems in West Asia and North Africa, 'New Directions for a Diverse Planet'," 4th International Crop Science Congress, Brisbane, 26 September-1 October 2004. www.cropscience.org.au

[42] FAO, "Irrigation in the Middle East Region in Figures: AQUASTAT Survey," 2008 Water Report 34, 2009. ftp://ftp.fao.org/docrep/fao/012/i0936e/i0936e08.pdf

[43] D. Rosenfeld, Y. Rudich and R. Lahav, "Desert Dust Suppressing Precipitation: A Possible Desertification Feedback Loop," Geophysics, Vol. 98, No. 11, 2001, pp. 59755980 .

[44] F. F. Al-Bayati, "Climatic Conditions and Their Impact on the Geographical Distribution of the Dust Storms Em- 
pirical Study at Al-Anbar Province," Anbar University, Journal for the Humanities, Vol. 1, 2011.

[45] B. O. Elasha, "Mapping of Climate Change Threats and Human Development Impacts in the Arab Region," United Nations Development Programme, Arab Human Development Report (AHDR), Research Paper Series, 2010. http://www.arab-hdr.org/publications/other/ahdrps/paper0 2-en.pdf

[46] P. C. D. Milly, K. A. Dunne and A. V. Vecchia, "Global Patterns of Trends in Streamflow and Water Availability in a Changing Climate," Nature, Vol. 438, 2005, pp. 347350. doi:10.1038/nature04312

[47] DAI CGCM3 Predictors, "Sets of Predictor Variables Derived from CGCM3 T47 and NCEP/NCAR Reanalysis," Version 1.2, Montreal, 2008, p. 17.

[48] World Bank, "Climate Change Knowledge Portal," Climate Change Unit Environment Department World Bank, 2012.

http://sdwebx.worldbank.org/climateportal/index.cfm?pag $\mathrm{e}=$ country_historical_climate\&ThisRegion=Asia\&ThisC Code $=$ IRQ

[49] GAP, "South-Eastern Anatolia Project: Latest Situation," 2006. http://www.gap.gov.tr/English/Genel/sdurum.pdf

[50] I. H. Olcay Unver, "Southeastern Anatolia Project (GAP)," International Journal of Water Resources Development, Vol. 13, No. 4, 1997, pp. 453-484. doi:10.1080/07900629749575

[51] S. Shams, "Water Conflict between Iraq and Turkey," Middle East News, 2006. http://www.mokarabat.com/m1091.htm

[52] Alnajaf News Net, "The GAP Project and Its Negative Implications on Iraq," 2009

http://www.alnajafnews.net/najafnews/news.php?action=f ullnews\&id=31503

[53] J. Waterbury, "Transboudary Water and the Challenge of International Cooperation in the Middle East," In: R. Roger and P. Lydon, Eds., Water in the Arab Word: Perspectives and Prognoses, Harvard University, Cambridge, 1993, pp. 39-64.

[54] M. Alsodani, "GAP Project and Its Economic Negative Implications on Syria and Iraq," Aletehad News, 2005. http://www.alitthad.com/paper.php?name=News\&file=pri nt\&sid= 19030

[55] National Defense Magazine, "Turkish Israeli partnership in GAP Southeastern Anatolian Project," Official Site of the Lebanese Army, 2009. http://www.lebarmy.gov.lb/article.asp?ln=ar\&id=2901

[56] Ministry of Irrigation Syria, "Constructed Dams in Syria till 2006," 2009. http://www.irrigation.gov.sy/index.php?d=114

[57] H. A. Kamona, "The Effect of Turkish Water Policy on Iraq," AlSabah Iraqi News Net, Baghdad, 2003.

[58] P. Beaumont, "Agricultural and Environmental Changes in the Upper Euphrates Catchment of Turkey and Syria and Their Political and Economic Implications," Applied Geography, Vol. 16, No. 2, 1996, pp. 137-157.

[59] S. Alyaseri, "GAP Project: Dangerous Consequences on
Life in Iraq," Official Site of Iraqi Council for Peace and Unity, 2009.

http://www.marafea.org/paper.php?source $=$ akbar\&mlf $=\mathrm{c}$ opy\&sid $=11556$

[60] C. Robertson, "Iraq Suffers as the Euphrates River Dwindles," The New York Times, 2009.

http://topics.nytimes.com/topics/reference/timestopics/pe ople/r/campbell_robertson/index.html?inline=nyt-per

[61] Y. A. Majeed, "The Central Regions: Problems and Perspectives," In: R. Roger and P. Lydon, Eds., Water in the Arab Word: Perspectives and Prognoses, Harvard University, Cambridge, 1993, pp. 101-120.

[62] I. Alalaf, "Ilisu Dam and Its Effect on Man and Environment in Iraq and Turkey, Batnaya," 2009.

http://www.batnaya.net/forum/showthread.php?s=9bd97a a8bfae0b9b35554d8ce6c2787e\&p=151263\#post151263

[63] BBC News, "Iraq's PM Warns Arab States May Face 'Water War'," 2012. http://www.bbc.co.uk/news/world-middle-east-18262496

[64] H. Janabi, "Water Security in Iraq," Iraqi's Ambassador to the UN Agencies in Rome 1, FAO Meeting, Alexandria, 1 April 2010.

[65] Stockholm International Water Institute (SIWI), "Water Resources in the Middle East, Background Report to Seminar on Water and Energy Linkages in the Middle East," 2009, p. 9.

[66] Inter-Agency Information and Analysis Unit, "Water in Iraq Factsheet," 2011.

http://www.iauiraq.org/documents/1319/Water\%20Fact\% 20Sheet\%20March\%202011.pdf

[67] Investors Iraq, "Water Crisis in Iraq: The Growing Danger of Desrtification," 2009.

http://www.investorsiraq.com/showthread.php?132306-W a-ter-Crisis-in-Iraq-The-Growing-Danger-of-Desertificati on\&s=bac86eb806dc1177231fc10190b17dbf

[68] Multiple Indicator Cluster Survey, "IRAQ: Monitoring the Situation of Children and Women," Final Report, 2007.

http://www.childinfo.org/files/MICS3_Iraq_FinalReport 2006 eng.pdf

[69] World Bank, "Food and Agriculture Organization," AQUASTAT, Renewable Internal, 2013.

[70] World Resources Institute, "Drylands, People, and Ecosystem Goods and Services: A Web-Based Geospatial Analysis," 2002. http://www.wri.org

[71] UNICEF, "Iraq Watching Briefs, Water and Environmental Sanitation," 2003. http://www.unicef.org/evaldatabase/files/Iraq_2003_Watc hing_Briefs.pdf

[72] Relief Web, "Water and Sanitation in Iraq," 2003. http://reliefweb.int/report/iraq/water-and-sanitation-iraq

[73] E. A. Jawaheri and R. A. Alsahmari, "Water Problems of Iraq and Possible Solutions," Journal of Law and Politics, Vol. 2, No. 1, 2009, pp. 9-61.

[74] A Climate for Change, "Water Supply and Sanitation in Iraq," 2012.

http://www.aclimateforchange.org/profiles/blogs/water-su 
pply-and-sanitation-in-iraq

[75] S. M. Ali, A. S. Mahdi, Q. M. Hussan and F. W. AlAzawi, "Fluctuating Rainfall as One of the Important Cause for Desertification in Iraq," Journal of Environment and Earth Science, Vol. 3, No. 2, 2013, pp. 25-33.

[76] N. Raphaeli, "Water Crisis in Iraq: The Growing Danger of Desertification, Investors Iraq," No. 537, 2009.

http://www.investorsiraq.com/showthread.php?132306-W ater-Crisis-in-Iraq-The-Growing-Danger-of-Desertification

[77] The Encyclopedia of Earth, "Water Profile of Iraq," 2008.
http://www.eoearth.org/article/Water_profile_of_Iraq

[78] C. Dempster, "Resilience of Social-Ecological Systems (SESs): A Case Study of Water Management in the Iraqi," Master's Thesis, Queen's University, Kingston, 2010.

[79] N. A. Al-Ansari, S. Knutsson and A. Ali, "Restoring the Garden of Eden, Iraq," Journal of Earth Sciences and Geotechnical Engineering, Vol. 2, No. 1, 2012, pp. 5388. 